Vol. 5, n`2 | 2001

Varia

\title{
Homicide in Early Modern England 1549-1800 : The Need for a Quantitative Synthesis
}

\section{Randolph Roth}

\section{(2) OpenEdition \\ 1 Journals}

Electronic version

URL: https://journals.openedition.org/chs/737

DOI: $10.4000 /$ chs. 737

ISSN: 1663-4837

Publisher

Librairie Droz

Printed version

Date of publication: 1 January 2001

Number of pages: $33-67$

ISBN: 2-600-00664-8

ISSN: 1422-0857

\section{Electronic reference}

Randolph Roth, "Homicide in Early Modern England 1549-1800 : The Need for a Quantitative Synthesis", Crime, Histoire \& Sociétés / Crime, History \& Societies [Online], Vol. 5, n² | 2001, Online since 02 April 2009, connection on 22 March 2022. URL: http://journals.openedition.org/chs/737 ; DOl: https://doi.org/10.4000/chs.737 


\title{
Homicide in Early Modern England 1549-1800: \\ The Need for a Quantitative Synthesis
}

\author{
Randolph Roth'
}

Scholars of early modern England have produced superb studies of crime and violence. Given the differences, however, in the sources, methods, and chronological range of their studies, it is difficult to construct a synthetic quantitative analysis of homicide from their findings. The essay offers a provisional quantitative synthesis of research on neonaticide and adult homicide, and argues that a comprehensive examination of the surviving evidence and an application of statistical techniques drawn from econometric and demography can lead to reliable estimates of early modern homicide rates.

Les spécialistes de l'Angleterre à l'époque moderne ont produit de remarquables recherches sur la criminalité et la violence. Toutefois, en raison des différences dans les sources, les méthodes employées et les périodes étudiées, il est difficile de construire sur cette base une synthèse quantitative des résultats concernant l'homicide. Le présent article propose une synthèse provisoire des travaux sur l'infanticide et l'homicide et avance la thèse selon laquelle un examen approfondi des données existantes et l'utilisation de techniques statistiques empruntées à l'économétrie et à la démographie peut conduire à une estimation fiable des taux d'homicide à l'époque moderne.

$\mathrm{N}_{\mathrm{m}}^{\circ}$ To nation has received the attention of a more gifted group of scholars of early modern crime than England. The work of Beattie (1986), Cockburn (1977, $1990)$, Hunnisett $(1969,1981,1985)$, and Sharpe $(1981,1983,1999)$ is renowned for its insight into early modern history and for its careful use of evidence. Given the differences, however, in the sources, methods, and chronological range of their studies, it is difficult to construct a synthetic quantitative analysis of homicide from their findings. The broad outlines are clear : homicide rates increased in England in the late sixteenth century and declined by the early eighteenth century. The extent and the precise timing of that rise and decline are not yet clear, however, especially for specific kinds of homicide, like neonaticide, which may have been caused by distinctive forces.

Beattie's study of criminal indictments for homicide and neonaticide in Surrey and Sussex counties, $1660-1800^{2}$, is well designed. Beattie uses population statistics

1 Randolph Roth is an Associate Professor of History at Ohio State University. He is a member of the Board of Editors of Historical Methods and the author of «Child Murder in New England» which appeared in the Spring 2001 issue of Social Science History, and «Spousal Murder in Northern New England, 1776-1865» which appeared in C. Daniels and M. V. Kennedy (eds.), Over the Threshold: Intimate Violence in Early America (Routledge, 1999). He is completing an interregional study of violent crime and violent death in the United States, titled «Why Northern New Englanders Seldom Commit Murder: How America Became a Homicidal Nation». The author thanks the National Science Foundation (Grant SBR-9808050) for its support.

2 Beatties (1986, pp. 77-124). 
carefully and acknowledges gaps in the records as he calculates homicide and neonaticide rates per 100,000 persons in the total population per year. He shows that homicide and neonaticide indictment rates declined steadily in urban and rural settings. Beattie's series rests, however, on a single source: the indictment files of the county courts of assizes and general gaol delivery. Homicides that did not lead to indictments in those courts are not included.

Cockburn (1990) uses the records of the county assizes and of the King's Bench to construct time series on homicides and neonaticides in Kent, 1559-1800. The records of the King's Bench contain inquests and file papers on homicides that came to the attention of county authorities but did not result in indictments. These include homicides that were legally justified as well as homicides in which the suspect had fled or in which the evidence was insufficient to bring an indictment against a particular person.

Cockburn finds that homicide rates surged in Kent in the 1580s and declined steadily through 1800 , except for brief upswings in the 1650s and 1670s. But Cockburn's impressive series has limits. First, it does not account for gaps in the assize records. That omission depresses its estimates of homicide rates, especially in the 1610s and 1620 s. Second, it does not account for the decline in returns to the King's Bench after 1600 or for the absence of such returns after 1660. A separate analysis of the King's Bench returns (which include inquests on suicides, casualties, and deaths from natural causes) is required to determine the completeness of the returns, so that homicide rates can be adjusted for partial or missing returns. And third, it estimates the early population of Kent arbitrarily by adding 2600 persons to the county population each decade from 1571 through 1691 . The method assumes that the growth rate of the population was high in the $1570 \mathrm{~s}$ and that it declined steadily through the $1680 \mathrm{~s}-$ an assumption not wholly consistent with the findings of historical demographers.

Sharpe ${ }^{3}$ uses a still wider array of sources to study homicide in Essex, 16201680. He consults the records of the county assizes, the King's Bench, and the borough courts (which were independent from the county assizes and King's Bench). Sharpe reports the gaps in each series of records. He does not, however, use that information to calculate homicide rates, nor does he report the number of homicides found each decade in the King's bench and borough records. That omission is critical, because the indictment totals reported from assize records and from all records do not coincide. The discrepancies are small, but they make it difficult to take advantage of Sharpe's work in the King's Bench and borough court records when calculating homicide rates ${ }^{4}$.

A study by Sharpe $e^{5}$ of homicide indictments brought before the Court of Great Sessions of the Palatinate of Chester, 1580-1709, also notes gaps in the records. Again, Sharpe does not use the data to calculate indictment rates.

Hunnisett $(1969,1985,1981)$ examines coroner's inquests returned to the King's Bench from Nottinghamshire, 1485-1558, and Sussex, 1485-1558, and all inquests conducted in Wiltshire, 1753-1796. Hunnisett reports gaps in these records, but he like Sharpe does not calculate homicide rates.

3 Sharpe (1983, pp. 123, 134, 136, 183).

4 Compare Tables 14, 15, and 19 in Sharpe (1983, pp. 134, 136, 183). Table 19 is based on a wider range of sources than Tables 14 and 15 , but it reports one fewer neonaticide ( 83 versus 84 ). It also reports two fewer homicide indictments in the 1640 s and one fewer in the 1650 s. Note that the number of homicide indictments brought before the assizes, quarter sessions, and King's Bench is either 201 (p. 123) or 209 (p. 183).

s Sharpe (1999, pp. 83, 88). 
The following essay attempts to synthesize these and other quantitative studies of homicide and neonaticide in early modern England. The data present a clear and consistent picture of the history of neonaticide and suspected neonaticide, once gaps in inquest and indictment series are taken into account and once investigation and prosecution rates are calculated per 100,000 births per year rather than per 100,000 persons in the total population. Rates of examination and prosecution did not rise or fall with changes in the law or in prosecutorial zeal, but with demographic and economic variables that impinged on the ability of young women to marry and support children. The evidence is strong that changes in the inquest and indictment rates for neonaticide reflected changes in the actual rate of neonaticide, which was determined by the cost of children relative to parental resources and to the ambitions of parents for themselves and their children.

The data on other homicides are difficult to synthesize. Most studies fail to examine the critical period of the Civil War or to disaggregate homicides into categories that are more liable to successful interpretation (such as child murder, spouse murder, or nondomestic murder). The data in existing studies suggest, however, that the surge in homicide indictments and inquests in the late sixteenth and early seventeenth century was caused by an increase in nondomestic murders among adults. Politics may have played as important a role in increasing the adult nondomestic homicide rate as did the economy, war, or culture. But without further research, it will be impossible to tell.

The final section of the essay discusses ways in which quantitative understanding of early modern homicide might be improved. A comprehensive examination of the surviving evidence and an application of statistical techniques drawn from econometrics and demography can lead to reliable estimates of early modern homicide rates.

\section{NEONATICIDE}

Much can be learned about neonaticide in early modern England from the studies of indictments and inquests that have been completed to date (Appendix A). Files of indictments and inquests are incomplete, even for the seven counties whose records survive from the period before the English Civil Wars. Cockburn (1975a) has edited and published the early records of the assizes of the Home Counties (Essex, Hertfordshire, Kent, Surrey, and Sussex). Table 1 shows the completeness of those records, 1559-1625. Counties held two assizes each year (except for Sussex, which may have held only one session a year prior to 1568). Partial returns from assizes are here considered missing, as it is impossible to determine the number of homicide indictments at such sessions. Most returns from the Home counties in later years and from the Palatinate of Chester have survived, but the gaps are sometimes substantial.

Once the proportion of the assize records or coroner's inquests that survived in each decade is determined, it is possible to extrapolate the number of homicide and neonaticide indictments or inquests that came before the courts in each decade. Following Beattie (1986), the number of indictments or inquests in the surviving records is divided by the proportion of the records that survived in each county in each decade. These estimates can then be used in conjunction with estimates of the county population and of birth rates (Appendix B) to determine indictment or inquest rates.

The resulting neonaticide indictment and inquest rates in early modern England (per 100,000 births per year) are reported in Figure 1. The rates are erratic. They 
Table 1:Completeness of Assize Records, 1559-1625.

\begin{tabular}{|c|c|c|c|c|c|c|}
\hline & Essex & Hertfordshire & Kent & Surrey & Sussex* & All terms \\
\hline $1559-69$ & 15 & 0 & 17 & 19 & 19 & 22 \\
\hline $1570-9$ & 19 & 7 & 16 & 18 & 16 & 20 \\
\hline $1580-9$ & 19 & 10 & 16 & 20 & 13 & 20 \\
\hline $1590-9$ & 16 & 14 & 18 & 18 & 18 & 20 \\
\hline $1600-9$ & 13 & 17 & 17 & 11 & 12 & 20 \\
\hline $1610-9$ & 16 & 20 & 8 & 15 & 11 & 20 \\
\hline $1620-5$ & 4 & 11 & 2 & 11 & 9 & 11 \\
\hline
\end{tabular}

* Counties held two assizes each year, except for Sussex, which apparently held only one session a year prior to 1568. Sussex sessions are thus counted twice through 1567. Source: Cockburn (1975a).

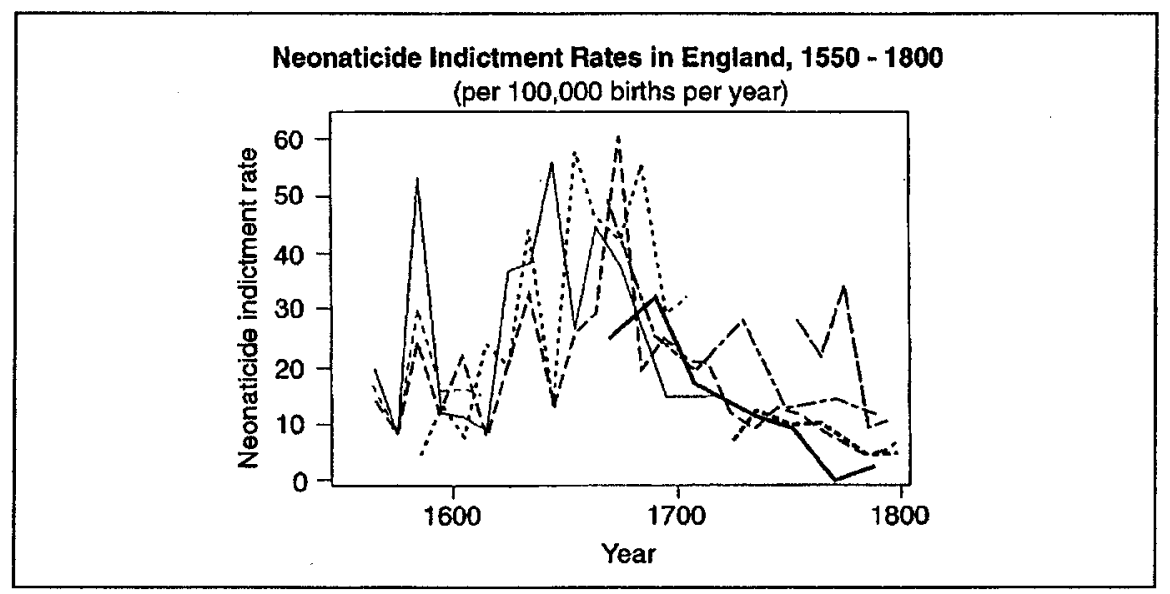

Figure 1.

reflect the short-term surge in neonaticide indictments that occurred in the $1580 \mathrm{~s}$, when real wages plummeted, war broke out with Spain, and famine struck. They also reflect the short-term decline in indictments that occurred in two counties during the 1640 s, when the Civil Wars disrupted law enforcement. The rates display as well the instability introduced by extrapolating decadal indictment rates from partial data.

When the indictment and inquest rates are smoothed, however, to resist the influence of outlying values ${ }^{6}$, a clear pattern takes shape (Figure 2). Rates varied from county to county, but the long-term trend was similar across counties.

6 The default resistant smoother in MINITAB was used. On resistant smoothers, see Velleman, Hoaglin (1981, pp. 159-181); McNeil (1977, pp. 119-130); Roth (1998, pp. 21-22). 


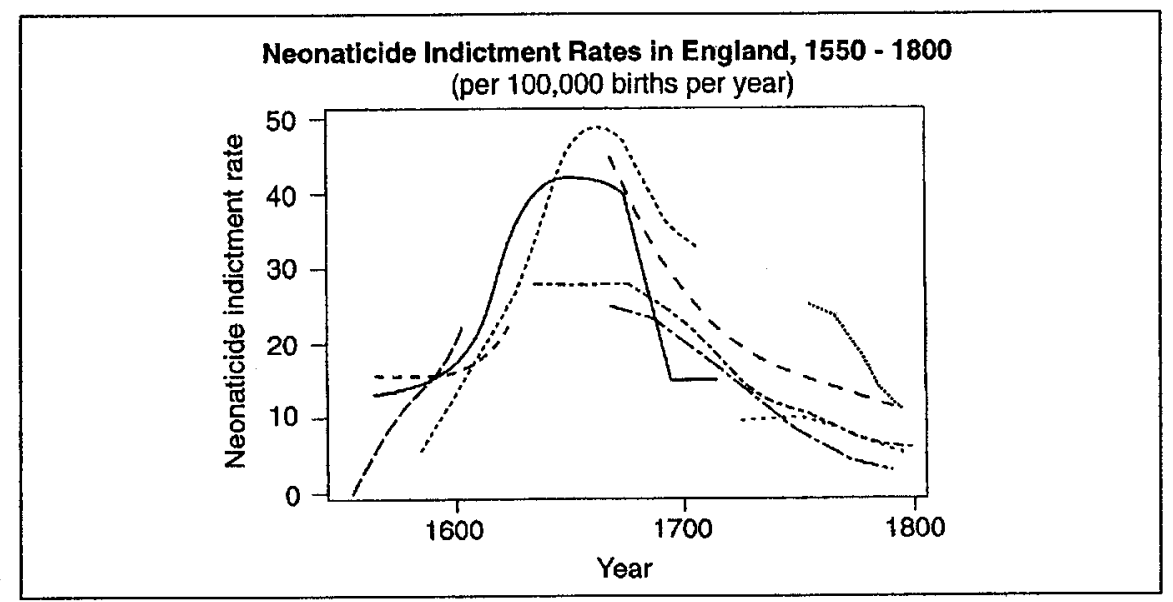

Figure 2.

Neonaticide indictment and inquest rates turned upward in the early seventeenth century. They peaked in the 1650 s through the 1680 s at two to five times the rates that had prevailed in the late sixteenth century. Rates then declined through the $1790 \mathrm{~s}^{7}$.

Indictment and inquest rates for neonaticides and suspected neonaticides may have reflected, of course, changes in the law and in prosecutorial zeal. The poor law of 1576 increased pressure on unwed parents ${ }^{8}$. The law gave parish officials new powers to punish unwed parents and to limit relief payments to illegitimate children. Unwed mothers were required to name their children's fathers and unwed fathers were required to post bonds or to submit weekly payments to support their children, on penalty of corporal punishment or imprisonment.

The new poor law incited acts of violence against unwed mothers. In 1577, officials in a Middlesex parish forcibly returned an unwed woman on the verge of giving birth to her home parish, so that the Middlesex parish would not have to support her child. The woman hemmorhaged during the trip and died of internal bleeding'. In 1600 , a tailor in Maldon, Essex, assaulted a young women who was pregnant with his

7 Note that the relationship between the curves for neonaticides and birth rates is too strong to be a statistical artifact of increases and decreases in the proportion of all children who are first-born. To the degree that the birth rate increases because of an increase in family size, the proportion of children who are first-born will decline. Since first-born children are at greatest risk of being murdered at birth, a rise in the birth rate because of increasing family size will produce a proportionate decrease in the neonaticide rate, if the proportion of first-born children who are murdered remains constant. Such an effect could account at most, however, for a third of the decline in the neonaticide rate in the seventeenth and early eighteen centuries. And the actual impact of that effect on the neonaticide rate is less, given that many widows and women separated from their husbands committed neonaticide against children who were not first-born, and that the birth rate increased in part because of an increase in the proportion of women who bore children. At any rate, the long-term decline and rise in neonaticide rates persists if the rates are calculated in relation to the number of women at risk of committing neonaticide (either women of childbearing age, ages 15 to 44 , or young women, ages 15 to 25), rather than in relation to the number of newborn children.

8 Slack (1988, pp. 17-36, 53-55); Hoffer, Hull (1981, pp. 13, 17-19).

9 Jeafferson (1886-1892, v. 2, p. 122). 
illegitimate child « to make the said childe to be untymelie borne.» To avoid paying child support, he beat her so unmercifully that he «crushed $»$ her belly, and she died ${ }^{10}$. In 1679, a laborer and the wife of a victualler in Wrotham, Kent, forcibly carried the victualler's ward, a young pauper described as «imbecile and great with child», to her home parish. She too died of injuries suffered during the trip ${ }^{11}$.

There is little evidence, however, that the Poor Law of 1576 increased neonaticide prosecutions or rates. The law may have contributed to a brief surge in neonaticide indictments in the $1580 \mathrm{~s}^{12}$. But the surge in that decade probably had less to do with the new law than with the peculiar economic pressures on unwed fathers and mothers in that decade. The poor laws, when enforced, may in fact have discouraged neonaticide. They forced unwed fathers to pay child support and promised unwed mothers adequate relief through their home parishes if the fathers of their children could not be brought to account. Few parishes levied rates to support the poor before the 1620s and 1630s. Only a third did so by the end of the Civil Wars. Poor relief improved dramatically only in the late seventeenth and eighteenth centuries, as parishes complied with the law and relief payments grew more generous ${ }^{13}$. So did provision for abandoned infants, as charity hospitals, churches, and overseers of the poor committed more resources to their care ${ }^{4}$. These improvements may have contributed to the decline in neonaticides and suspected neonaticides after the Glorious Revolution.

The 1624 law on infanticide increased the number of neonaticide indictments by declaring that a woman who concealed the birth and death of an illegitimate child was guilty of a capital crime, even if it could not be proved that the child had been born alive ${ }^{15}$. The law reflected the frustration of Parliament with the rising tide of suspected neonaticides and with the ability of suspects to escape capital punishment because of the difficulty of proving the cause of newborn deaths. The increase in neonaticide indictments in the late 1620 s and 1630 s was small, however, relative to the surge in prosecutions that occurred in the 1650s and after. Indeed, if stillbirths reported to the county courts from 1559 to 1623 are added to list of suspected neonaticides, the sudden increase in indictments in the mid-1620s disappears. The 1624 law changed the likelihood of indictment, not the likelihood of complaint.

Increased zeal to punish persons who had sexual relations out of wedlock may also have had an upward impact on neonaticide indictments. A broad movement for the «regulation of manners» (including sexual conduct) gained strength in England from the $1580 \mathrm{~s}$ through the 1640s. The movement intensified the stigma of unwed motherhood $^{16}$. But neonaticide investigations and indictments peaked after the Restoration, when Puritanism and moral reform were in decline. In short, indictment and inquest rates rose too strongly and too late for legal or prosecutorial explanations to suffice.

Legal change and prosecutorial zeal also cannot account for the decline in neonaticide indictments and inquests after the 1680s. Convictions for neonaticide

10 Cockburn (1975b, case 3057).

11 Cockburn (1977, case 554).

12 Hoffer, Hull ( 1981, p. 13, 17-19).

13 Slack (1995, pp. 22-34, 53-56).

14 Fildes (1990, pp. 139-178).

15 Hoffer and Hull (1981, pp. 3-31).

16 Wrightson, Levine (1979, pp. 124-134); Ingram (1985, pp. 150-159); Ingram (1987); Ingram (1996, pp. 47-88); Beattie (1986, pp. 400-618); Underdown (1985, pp. 9-72); Adair (1996, pp. 128-187, 224-225). 
nearly disappeared as medical practitioners raised doubts about the primitive proofs that had been used to establish whether children had been born alive. Could a coroner determine whether a child had once been alive by measuring the length of its hair or nails, or by testing to see if pieces of its lungs could float in water? Just as physical maturity was not an absolute guarantee that a child had been born alive, floating lung tissue was no proof that a child had taken a breath. Autopsies had already proven that gas emitted by decomposition could cause a stillborn child's lungs to float and that lung tissue from children born alive could sink. As lawyers made better use of medical testimony and of the rules of evidence, jurors became more reluctant to convict unwed mothers. For example, on the Northern Circuit (Yorkshire, Cumberland, Westmorland, Northumberland), only six women were convicted for neonaticide and only two hanged from 1720 to 1800 . But nearly two hundred cases of suspected neonaticide were brought before the court. Society's determination to identify the murderers of newborns and to shame them publicly was still strong, but the willingness to punish them was not ${ }^{17}$.

The increase in the rate of neonaticides and suspected neonaticides in the late sixteenth and seventeenth centuries coincided, however, with a decline in the ability of young men and women to establish independent households and to support children. The birth rate in England dropped by a third from the 1570s to the 1660s and did not recover until the eighteenth century (Figure 3 ). The primary cause was a pre-

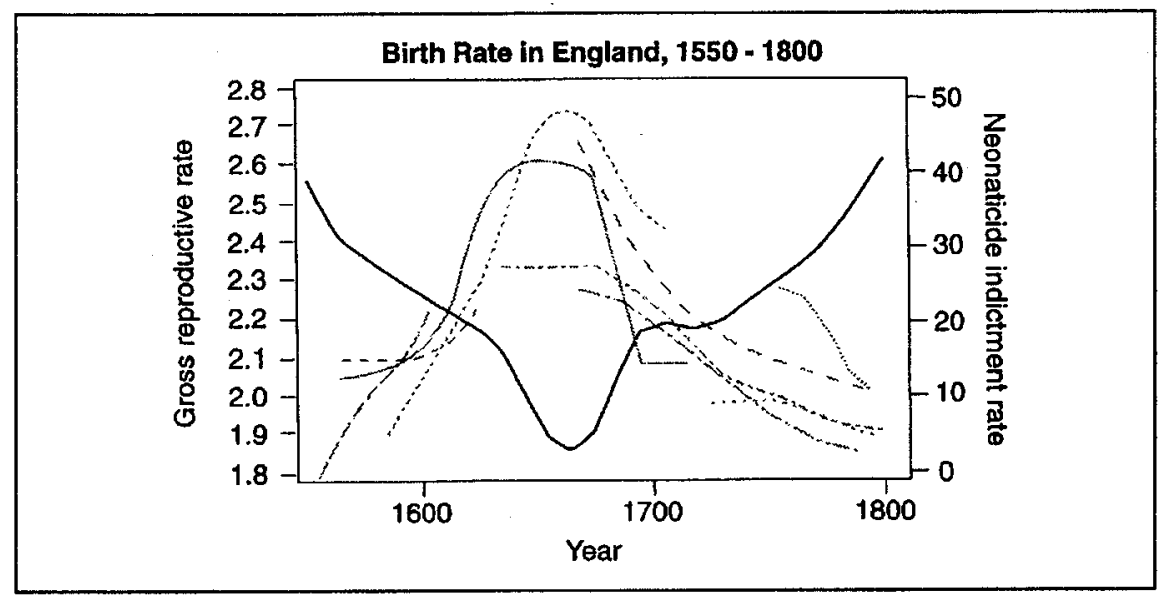

Figure 3.

cipitous decline in real wages (Figure 4). Real wages fell, according to various estimates, between a fifth and a third from the 1570 s and the 1630s. Economic production, especially in agriculture, did not grow as fast as population. The birth rate followed real wages with a lag of twenty years. Each generation adjusted its fertility in light of the economic experience of its parents' generation and of the resources it could expect to inherit from its parents. It took a full generation for a sustained economic downturn or upswing to affect fertility.

17 Jackson (1996, pp. 49; 51, fn. ; 55, fn., 39; 133-157); Beattie (1986, pp. 113-124); Malcolmson (1977, pp. 197-198). 


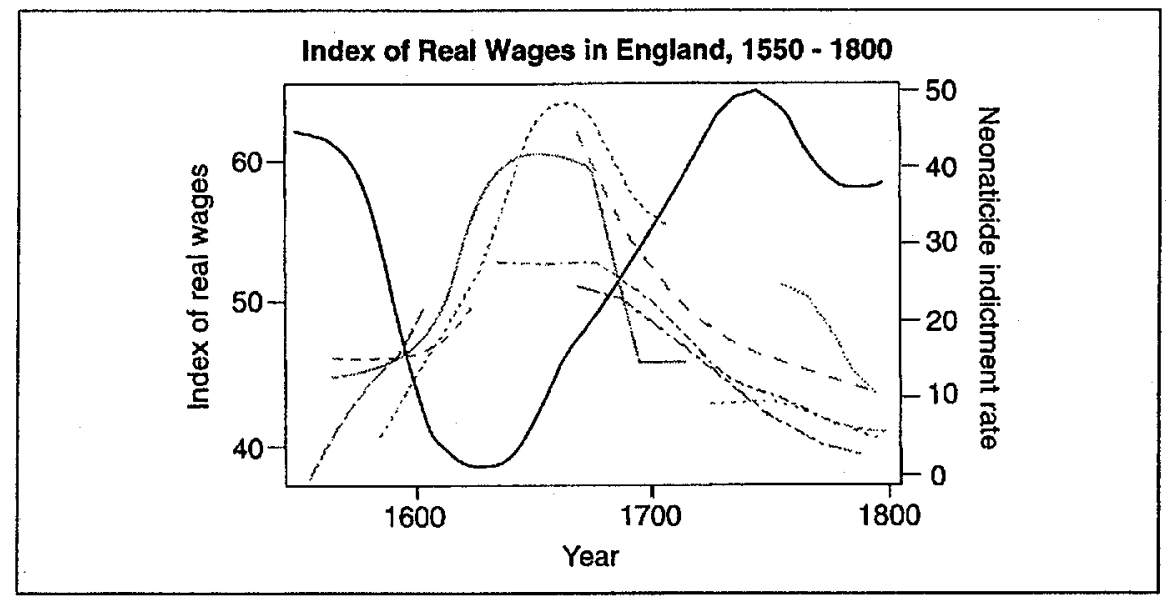

Figure 4.

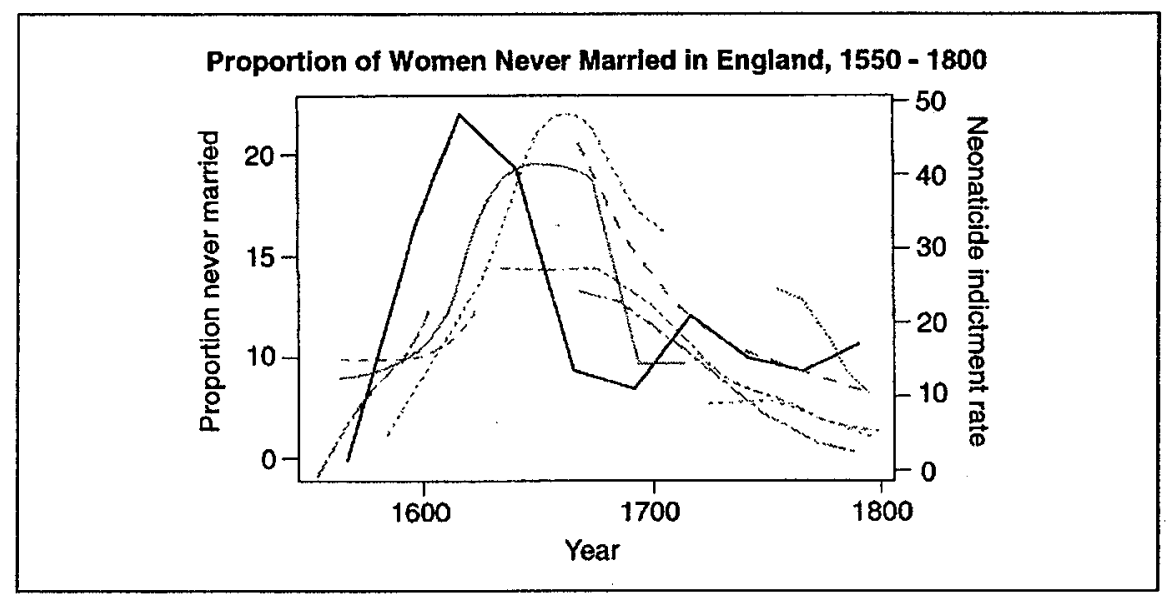

Figure 5.

The means that English men and women used to limit their fertility in times of economic dearth and demographic crisis placed extraordinary pressure on young, poor, unmarried women - the suspects in nearly every alleged case of neonaticide. The proportion of women who never married soared from five percent in the midsixteenth century to twenty percent in the first half of the seventeenth century, and then stabilized at over ten percent (Figure 5). That meant that a substantial portion of poor women could never hope to have families or households of their own. The average age at first marriage for women in the mid-seventeenth century was nearly 27 years old (Figure 6). Single young women came under intense pressure to abstain from sexual activity for the sake of their economic and marital prospects. The proportion of children born out of wedlock fell from nearly $4 \%$ in the late sixteenth century to $1.5 \%$ in 1660 s and $1670 \mathrm{~s}$ (Figure 7 ). Only in the late seventeenth and 


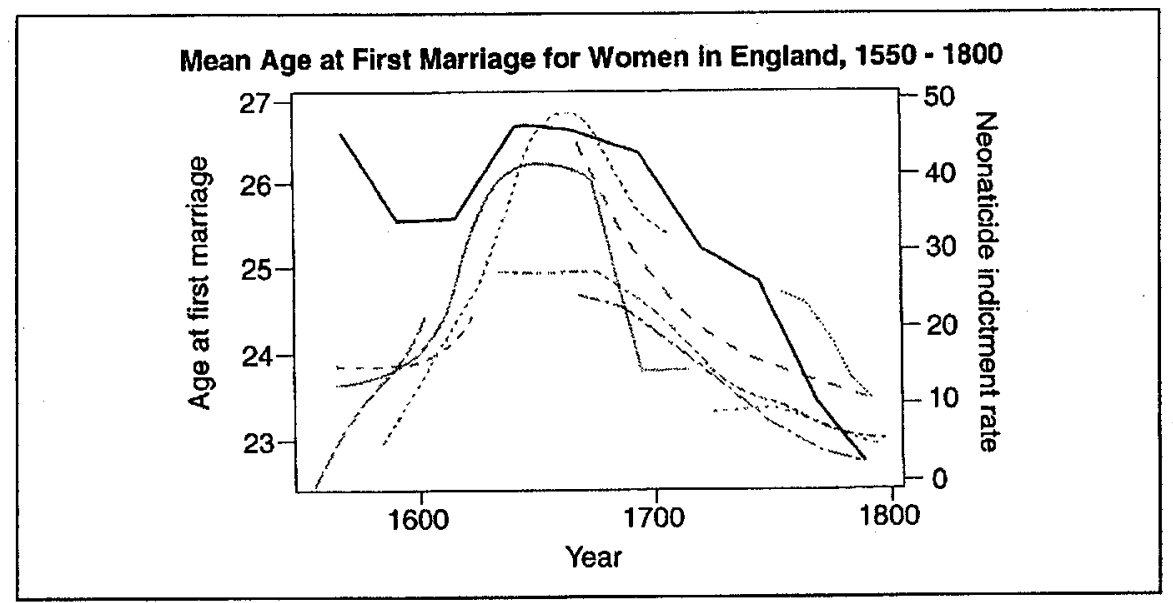

Figure 6.

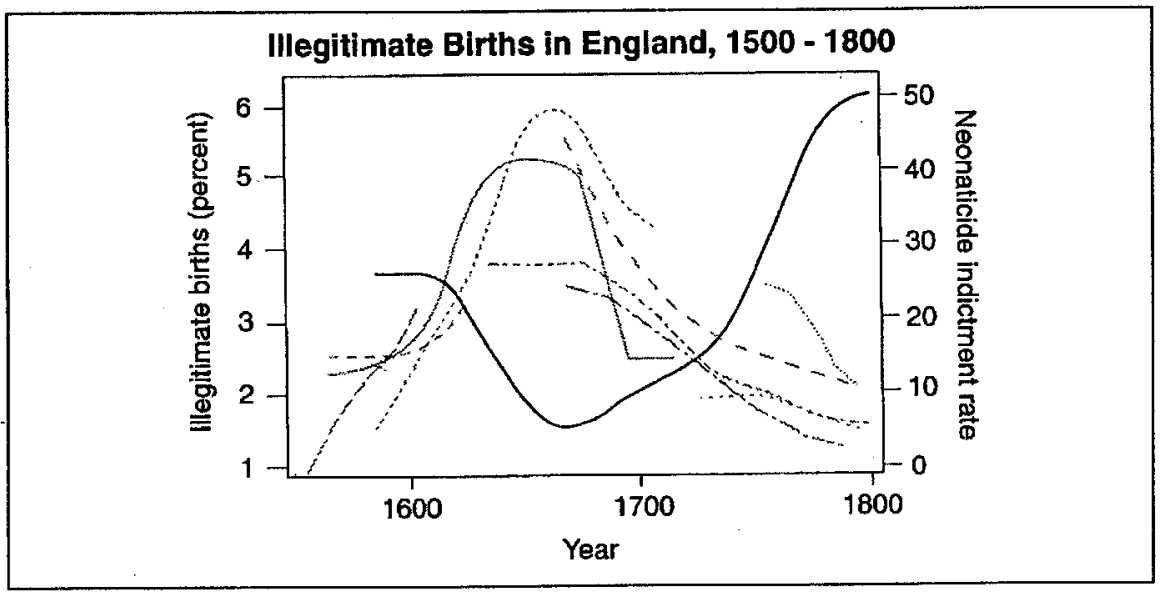

Figure 7.

eighteenth centuries, when real wages and birth rates rose and the age at first marriage fell, did the pressure on young unwed women ease.

The English did not use neonaticide to control their fertility. Although neonaticide rates had risen, individual instances of suspected neonaticide, including those that did not result in indictment, were too few, and the fertility of married women was too high for that to be the case. The English married late and practiced pre-marital abstinence ${ }^{18}$. These measures did not decrease the birth rate sufficiently to prevent a decline in the quality of life of people born in the seventeenth century. Life expectancy for newborn children fell by eight years between the 1570 s and the 1670 s

18 Wrightson, Levine (1974, pp. 63-72); Levine (1987, pp. 38-93); Houston (1995, pp. 67-75); McLaren (1984, pp. 129-135). 


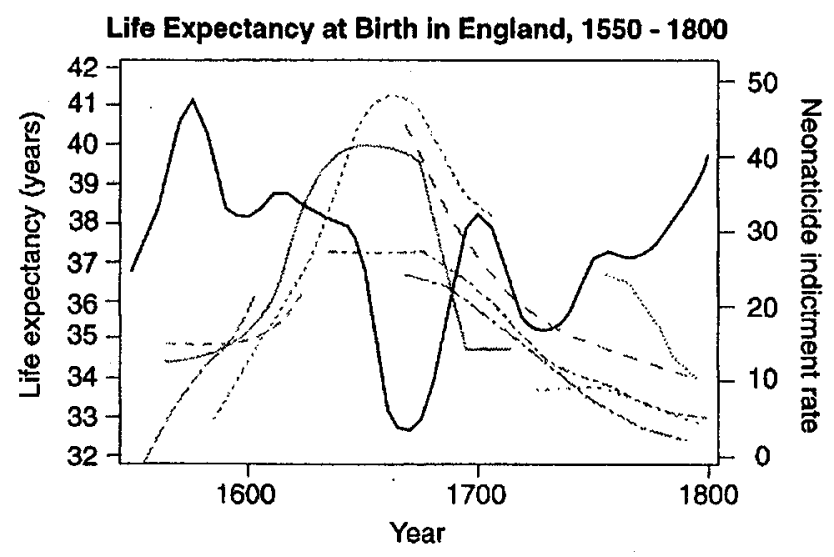

Figure 8.

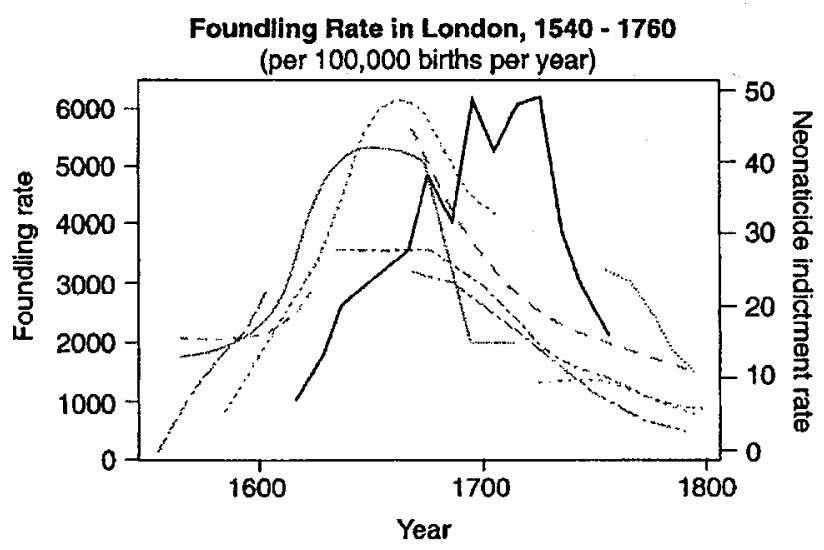

Figure 9.

(Figure 8). Poverty and poor nutrition took their toll. So did abandonment. In London, the rate at which children were abandoned jumped sharply from the $1650 \mathrm{~s}$ through the 1690s - the same decades that neonaticides peaked (Figure 9). London's overseers of the poor made every effort to find homes for these foundlings, most of whom were less than a year old. But except for those children who were adopted or placed with wet nurses in the countryside, foundlings died at a horrendous rate. Only in the eighteenth century, as the economy improved and the rate of abandonment declined, did the overseers have sufficient resources to care for abandoned children ${ }^{19}$.

19 Fildes (1990, pp. 139-178). 
Selective neglect may have also played a role in the decline in life expectancy. Parents may have provided more food and better care to healthier, older children who stood the best chance of survival and could contribute to the household income. Selective neglect, which was common in preindustrial agricultural societies that censured neonaticide and lacked effective means of contraception and abortion, would not have targeted either boys or girls in early modern England. Both were vital to the family economy. But selective neglect probably affected many poor children ${ }^{20}$.

The decline in the birth rate and in family size was sufficient to avert famine and starvation. The success the English had in lowering the birth rate may account for the low rate of neonaticide in England compared to some other early modern nations that experienced economic and demographic crisis in the seventeenth and eighteenth centuries. In Japan, peasant families murdered as many as thirty percent of all newborn children to keep the population in check and to maintain a rough balance within households of male and female children, who were equally vital, given the gender division of labor in rural Japan, to the economic welfare of households ${ }^{21}$. (In China, families murdered a similar proportion of newborns, but those killed were disproportionately female, since girls were considered less important both as workers and heirs $^{22}$. The measures that the English used to control fertility in the mid-seventeenth century were less drastic. But they did put women who were poor, young, unmarried, and pregnant in a perilous situation, particularly if they worked as domestic servants in respectable homes and aspired to have respectable homes themselves. As Malcolmson (1977), Wrightson (1975), Sharpe (1999, p. 158), Gowing (1996, 1997), and Jackson (1996) have shown, they faced shame, public humiliation, and the loss of their positions. As unmarried mothers, they could secure only the most demeaning jobs, and the stigma of unwed motherhood discouraged suitors and diminished their chance of marriage. It is no surprise that the majority of women indicted for neonaticide were young domestic servants. Their plight explains why neonaticide and suspected neonaticide rates increased dramatically in England.

Neonaticide rates may not have increased simultaneously in Scotland or Ireland. The Irish had substantial reserves of uncultivated land in the seventeenth century and felt less pressure to control their fertility ${ }^{23}$. The Scots felt the same pressures that the English did, but they did less to limit their fertility. The average age of women at first marriage was lower than in England, and the proportion of illegitimate births higher. It appears that the Scots accepted a lower standard of material comfort, a higher rate of unwed motherhood, a less expensive (though nutritious) diet based on coarse grains, and by the eighteenth century higher levels of emigration ${ }^{24}$. Culture as

20 Johansson (1984, pp. 463-486); Mul, Mull (1987, pp. 12, 113-132); Schleper-Hughes (1982, pp. 143); Hrdy (1999, pp. 79-83, 288-317).

21 Smith (1977); Hanley, Yamamura (1977); LaFleur (1992, pp. 69-118).

22 Lee et al. (1992, pp. 145-176); Lee, Fen (1999, pp. 7-9, 47-51, 57-62, 105-113).

23 Neonaticide did become a problem in Ireland in the eighteenth century, by which time population growth and low productivity left the Irish vulnerable to famine and economic downturns. The neonaticide rate in Dublin was 32 per 100,000 births per year from 1780 to 95 . Kelly (1992, pp. 5-26); Henry (1974, pp. 37-38); Kelly (1991-1992); Kelly (1992-1993); and Kennedy, Dowling (1997, pp. 62-104).

24 Adair (1996) finds considerable regional variation in illegitimacy rates in England before 1650. Rates were highest in the Highlands: the area north of a line drawn roughly between Hull and Exeter. It may prove that the culturally-sanctioned preference among young people in the Highlands (including Scotland) for betrothals, informal unions, and trial marriages placed young women under less pressure to commit neonaticide, Houston (1995, pp. 25-28, 34, 39, 76-79); Blaikie (1993). 
well as demographic and economic circumstance may have determined neonaticide rates. But in continental Europe, the pressure on young unmarried women to control their fertility was if anything more intense than that in England, because war took the lives of so many young men and impoverished so many families. The Dutch Revolt, the French Civil Wars, the Thirty Years' War, and other conflicts contributed to high levels of child abandonment and neonaticide in the Netherlands, France, Italy, Spain, and Germany from the sixteenth through the eighteenth centuries ${ }^{25}$.

\section{HOMICIDES}

It is far more difficult to synthesize the findings on homicides of older children and adults in early modern England. The available series of indictment and inquest rates (Figure 10) do not follow as clear a pattern as the series for neonaticides, even when the three counties with atypically high indictment rates - Chester, Sussex, and Middlesex - are excluded (Figure 11) and even when the rates are smoothed (Figure 12). The problem stems in part from the aggregation of all nonneonaticides into single homicide series. Only two studies distinguish among particular types of homicide $^{26}$, so it is impossible to tell if child murders, spouse murders, tobbery murders, etc., followed different patterns. Such disaggregated patterns may make more sense historically and theoretically ${ }^{27}$. The failure to extend the series of Hertfordshire, Surrey, and Sussex across the years of the Civil Wars also presents a problem. The rates for Cheshire, Essex, and Kent do not follow the same pattern in

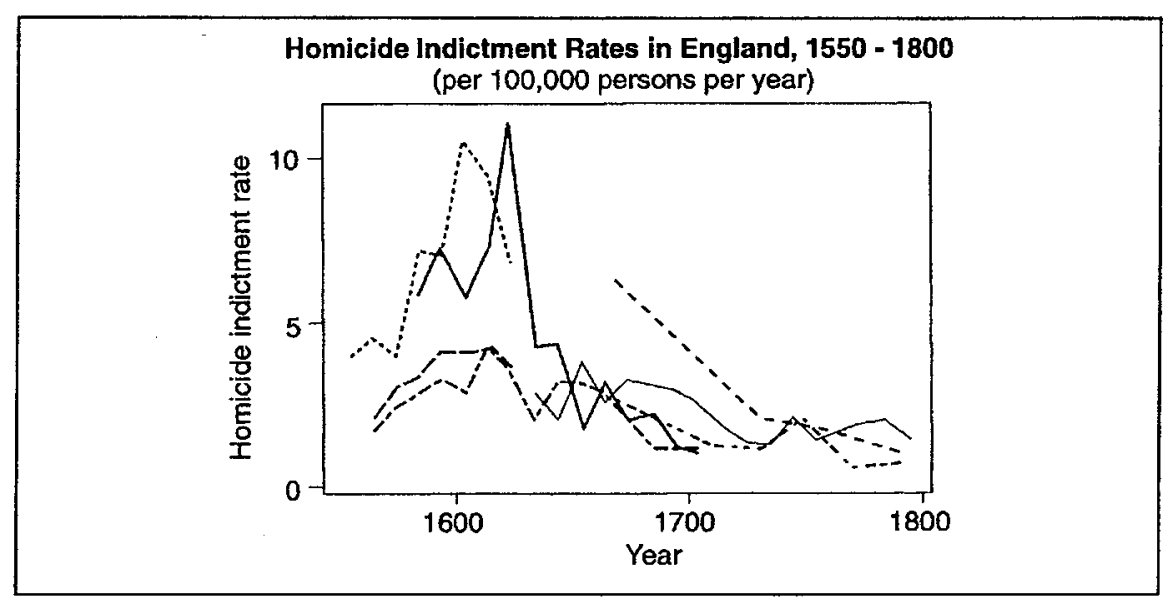

Figure 10.

25 Van Nierop (1959, pp. 154-155), Faber (1978, pp. 224-240), Van Eeghen (1956, p.130), Jansen (1978, pp. 109-110), Spierenburg (1996, pp. 85-86), Delasselle (1978, pp. 47-82), Hufton (1974, pp. 333-336), Kertzer (1993), Martz (1983, pp. 224-236), Michalik (1997, pp. 22-174). See also Boswell (1988).

26 Cockburn (1990); Sharpe (1981).

27. Spierenburg (1996, pp. 67-76). 
Homicide Indictment Rates in England, 1550 - 1800

(per 100,000 persons per year)

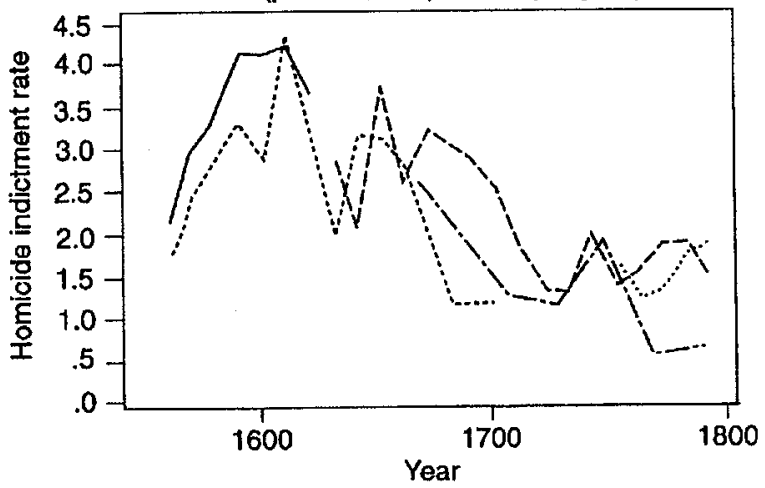

Figure 11.

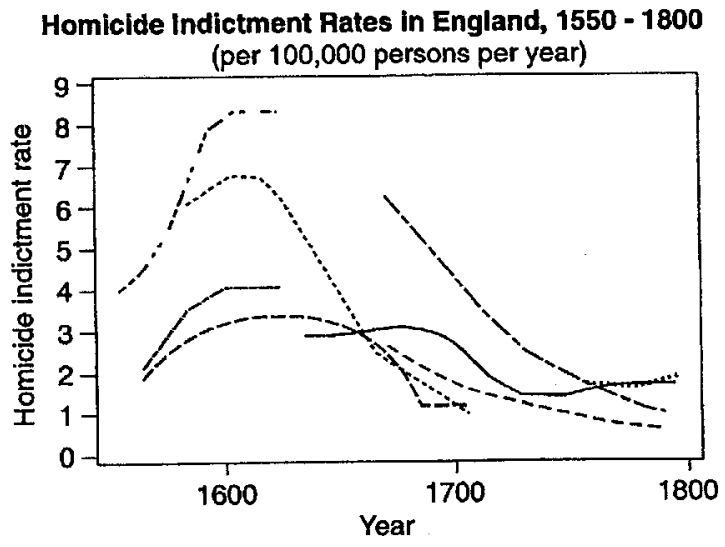

Figure 12.

those years, and Surrey county, which had a middling homicide indictment rate in the $1620 \mathrm{~s}$, had a high rate in the 1660 s and 1670 s, suggesting that it followed a distinctive path from 1630 to 1660 .

A general pattern does emerge, however. Homicide indictment and inquest rates, which were moderate in the 1560 s and $1570 \mathrm{~s}$, rose sharply in the $1580 \mathrm{~s}$ and $1590 \mathrm{~s}$ and peaked in the $1600 \mathrm{~s}$ and $1610 \mathrm{~s}$, a half-century before neonaticide rates did. The rates receded in the 1620 s and 1630 s, but they did not fall to the levels that had prevailed in the mid-sixteenth century until the early eighteenth century. Indictment rates were highest in the London suburbs of Middlesex and Surrey and in Cheshire, but rates were still substantial in the predominantly agricultural, economically advanced, and heavily Puritan counties southeast of London. The actual homicide rate in England in 
the early 1600 s was probably 15 per 100,000 persons per year ${ }^{28}$ : nearly as high as the rate of 18 to 23 that had prevailed in most jurisdictions in the thirteenth century ${ }^{29}$.

Most scholars believe that demographic pressure, economic depression, crop failures, the militarization of culture, and military demobilization together caused homicide rates to soar in the late sixteenth and early seventeenth centuries ${ }^{30}$. The years from the 1580 s through the 1610 s were years of intense economic hardship. Real wages dropped sharply and harvests failed in 1586, 1590,1595, 1596, and $1600^{31}$. Hunger, unemployment, vagrancy, and theft were rife, raising fears that the social and political order had collapsed ${ }^{32}$. Demographic pressure and economic change led in most communities to an increase in social stratification and to sharper divisions between the propertied and the poor and between community members and outsiders ${ }^{33}$. England was also involved in foreign wars continuously from 1585 to 1604 . The crown conscripted roughly $15 \%$ of the nation's able-bodied men, ages 15 to 59 , and schooled them in the art of personal combat. Most conscripts returned home destitute and many could not find work ${ }^{34}$. By the end of sixteenth century, « the overspill» of London criminals and paupers « into the markets and highways of the Home Counties was recognized as a serious problem», and thieves and robbers, many of them "vagrant and deserting soldiers", besieged every major town and highway in the region ${ }^{35}$. The nondomestic homicide indictment rate rose in the Home counties from 1.83 per 100,000 persons per year from 1559 to 1579 to 3.23 per 100,000 persons from 1580 to 1619 . Three-fourths of the assailants in nondomestic murders were armed for combat with blunt or sharp weapons : cudgels, pikestaffs, daggers, and swords. "In early modern England both prudence and fashion dictated the bearing of arms $»^{36}$. Late Elizabethan and Jacobean theatre, with its affairs of honor and bloody combat, reflected the stuff of everyday life.

The domestic homicide rate, however, may not have increased. The indictment rate in the Home Circuit counties for murders of relatives (including spouses) and of unrelated household members (servants, masters, and mistresses) held steady at 0.68 per 100,000 persons per year from the 1560 s through the 1610s, and in Essex County at 1.05 per 100,000 persons per year from the 1560 s through the 1650 s (calculated from Sharpe, 1981, p. 34), even though, as Bowden (1976, p. 621) observes, the decades from the 1590 s through the 1610 s were «among the most terrible years through which the country has ever passed». Whether that pattern holds for all counties is uncertain, but if it does, it is possible that domestic and household relationships were more durable than others. Historians of early modern England have found that relationships between husbands and wives, parents and adult children,

\footnotetext{
Sharpe (1996, p. 22).

Sharpe (1988); Gur (1981, pp. 304-308, 312-315).

Cockburn (1990, pp. 82-90); Sharpe (1999, pp. 263-268).

Walter, Schofield (1989, pp. 21-25); Lawson (1986, pp. 107-109).

Beier (1974, pp. 1-29); Emmison (1976); Slack (1974, pp. 360-379); Walter (1989, pp. 75-128);

Walter, Wrightson (1976, pp. 22-42); Wrightson, Levine (1974).

33 Excellent community studies include Wrightson, Levine (1974, 1991), Spufford (1974), Underdown

(1992), Hey (1974), McIntosh (1991), Zell (1994), Skipp (1978), Rowlands (1972), Tupling (1927).

See also Beier (1985), Slack (1988, 1995), Wrightson (1982, pp. 222-228).

Lawson (1986, p. 114-117).

35 Cockbum $(1977$, pp. 52, 61, 65-71; 1990, pp. 79-86).

Cockburn (1977, pp. 83-84).
}

36 
and masters or mistresses and apprentices or servants were more flexible and affectionate than once thought. Household members may have appreciated their interdependence and have formed a united front in the face of economic hardship ${ }^{37}$. Domestic relationships were hierarchial, of course, and wives and servants (the subordinates in those relationships) were two to three times more likely to be murdered than husbands, masters, and mistresses ${ }^{38}$. But killings were more often than not unintended. A servant who lingered too long in bed after an illness was beaten to death by an irate master; another master killed a servant who lingered too long while feeding the pigs. A husband killed his wife when she berated him for drinking too much; a wife killed her husband when he criticized her spendthrift ways ${ }^{39}$. Such violence began as an effort to assert authority or resist it: in that regard it was instrumental rather than murderous, meant to change behavior rather than kill. Instrumental violence was common when marriages or master-servant relationships broke down $n^{40}$. But such violence remained for the most part nonlethal.

The increase in lethal violence in the late sixteenth and early seventeenth centuries took place outside the home. The character of nondomestic homicides, which occurred during feuds, duels, tavern brawls, rapes, and robberies, suggests that relationships among friends and neighbors had become more volatile, and that many outsiders had become profoundly alienated from society. Why relationships among friends, neighbors, and strangers were more often fatal during the late sixteenth and early seventeenth century was not merely a question of economic hardship or military mobilization, but of «the politics of neighbourhood $»^{41}$. The crisis of the late sixteenth and early seventeenth centuries altered relationships among unrelated persons in ways that encouraged homicidal violence.

The institutions that communities had used to restrain conflict, maintain order, and provide for the destitute came under intense strain. As most scholars of Tudor and Stuart communities caution, those institutions seldom broke down, and were in many instances strengthened or augmented. Sharpe (1999, p. 130), who emphasizes the continuing orderliness of Tudor and Stuart society, acknowledges that the homicide rate rose dramatically in parishes adjacent to London, «notably in urban Middlesex, which were marked by a rapidly growing population, a high population turnover, and comparatively weak parochial institutions $\gg$. But in London, where parish institutions (e.g., church courts, poor relief) were strengthened and law enforcement improved, homicide and other crimes were less common (Archer, 1991). Herrup ${ }^{42}$ notes a similar pattern. Loosely governed counties, like Cheshire and Sussex, had higher rates of homicide and other crimes than Essex, Hertfordshire,

37 Wrightson (1996, pp. 13-18); 1982, Ch. 3 \& 4); Foyster (1999); Ingram (1985, pp. 132-137); BenAmos (1994), Emmison (1976, pp. 95-118).

38 Sharpe (1981, pp. 29-48); Cockburn (1977, p. 57).

39 On violence against servants, see Cockburn (1975b, case 913) and Cockburn (1982, cases 484, 817 . $1189,1520)$, and Jeafferson $(1886-1892$, v. 2, p. 100). On violence against spouses, see Jeafferson (1886-92, v. 1, pp. $27,50,185,212,221)$.

40 Foyster (1999, pp. 181-198, and 1996), Hunt (1992, pp. 10-33), Wiener (1975, pp. 43-44), Amussen (1994, pp. 70-89, and 1995), Gowing (1996, pp. 206-231). On popular views of spousal and household violence, see Dolan (1994, pp. 1-120).

41 Wrightson (1996, pp. 18-22).

42 Herrups (1987, pp. 29-40). 
and Surrey, counties that felt the impress of reform zeal, active government, and the discipline imposed by a commercializing economy (Table 2$)^{43}$.

Table 2: County Homicide Indictment Rates, 1559-1625.

\begin{tabular}{|l|c|c|}
\hline & Lowest decadal homicide rate & Highest decadal homicide rate \\
\hline Cheshire & 5.8 & 11.0 \\
Middlesex & 4.0 & 10.6 \\
\hline Sussex & 3.1 & 6.3 \\
Kent & 2.9 & 5.5 \\
\hline Essex & 1.7 & 4.4 \\
Surrey & 1.3 & 4.0 \\
Hertfordshire & 1.5 & 4.0 \\
\hline
\end{tabular}

But scholars have yet to determine which relationships in less violent counties were less violent. Did more strictly governed counties restrain lethal violence among all citizens or merely among the middle classes, who emerged from the crisis of the late sixteenth century with a stronger sense of social solidarity and an awareness of a need to band together to control, relieve, and minister to the poor? Quantitative evidence on lethal and nonlethal assaults would help answer that question, by indicating whether the increase in violence occurred among the poor, between the middling and the poor, or within all social groups and among all members of the society. Quantitative studies of homicide, however, have not yet gathered that data.

It is equally difficult, given the limits of existing quantitative studies, to know why homicide rates declined somewhat in the 1620 s or 1630 s. The economy did not improve substantially. The birth rate fell, as men and women tried to bring their fertility into line with their resources, but real wages did not rise until the 1650s. Many local governments enforced regulatory laws against disorderly alehouses, sexual license, and drunkenness with greater zeal, but homicide rates also fell in Cheshire, Middlesex, and Sussex, where such initiatives did not prevail. The absence of foreign wars from 1604 to 1625 dissipated the impact of two decades of militarization and demobilization, and the success of all but one harvest in the first four decades of the seventeenth century lessened what Slack $(1988$, p. $38-40,48-55)$ calls the «crisis level» of poverty, even if the «background level» of persistent poverty held steady. But again, it is critical to know which nondomestic relationships were less violent. Armed robbery soared in Essex during the Civil Wars and did not subside until the 1670s (Figure 13), which suggests that at least some strangers remained alienated and out of control. Unarmed thefts diminished rapidly, however, in Cheshire after 1620 (Figure 14), indicating that the poor who were not strangers to the community - the suspects in most thefts - were under greater surveillance or that poor relief had become more effective and reliable. Whatever the case, the declines in homicide and in nonviolent property crime suggest a lessening of social

43 See also Wrightson (1980, pp. 21-46, 1982, pp. 222-228), Hindle (1996, pp. 213-248), Sharpe (1999, pp. 102-134), and Beattie (1984, pp. 36-60). 


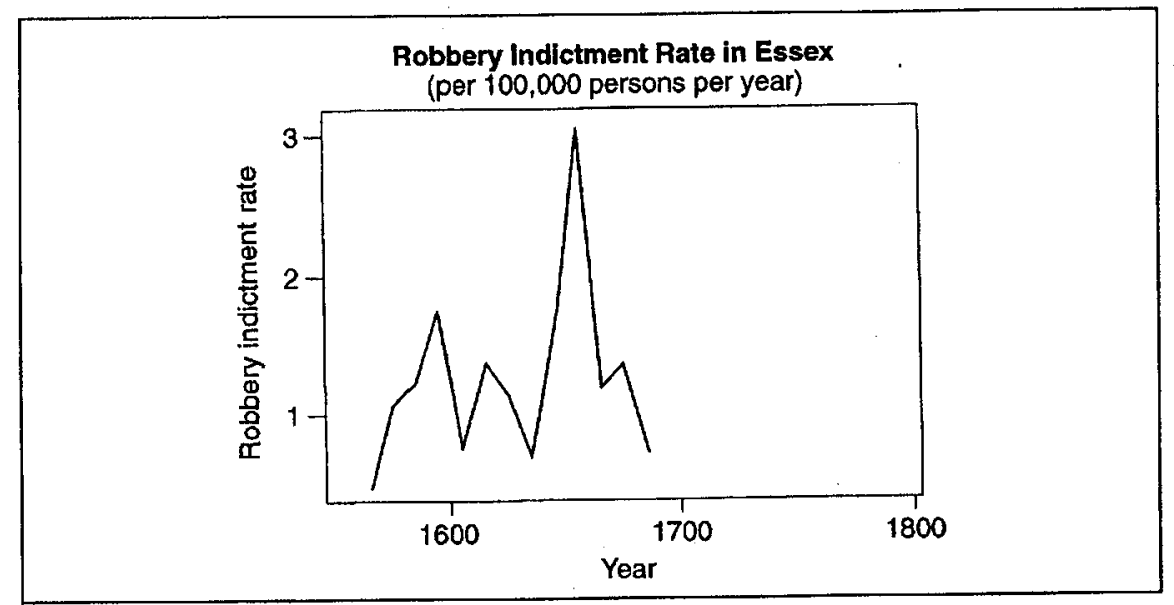

Figure 13.

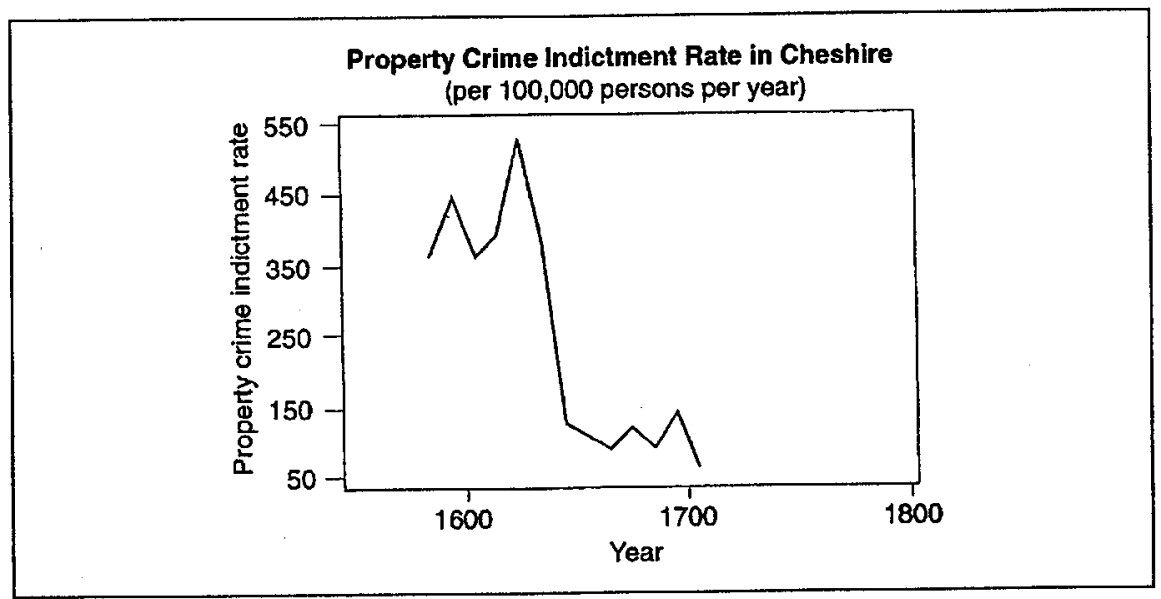

Figure 14.

tensions or a strengthening of social bonds or controls among neighbors, which may help explain the unity of sentiment and support for local elites and local interests in the Home Counties and in the Cheshire Palatinate during the national political crisis of $1640-42^{44}$. Only under the pressure of external military and institutional force did a substantial portion of the populations of these counties side with the Royalists or Parliamentarians ${ }^{45}$.

44 Everitt (1966); Holmes (1974); Morrill (1974).

45 Morrill (1999), Underdown (1985). 
The persistent decline in homicide rates after the Civil Wars is likewise difficult to explain. All the competing theories have merit. Cockburn ${ }^{46}$ and Beattie believe that a cultural shift toward empathy and civility restrained violence. Sharpe ${ }^{47}$ agrees that cultural change played an important role, but he emphasizes as well the improvement of the economy, the relaxation of demographic pressure, and the increasing power of the state in diminishing violence after the Civil Wars. It is possible that still other forces diminished violence among neighbors and among strangers: political stability, religious toleration, the expansion of poor relief, a renewal of faith in English institutions, and the rise of English patriotism and national solidarity, particularly after the Glorious Revolution and the onset of King William's War ${ }^{48}$. It may prove impossible to assess the relative importance of such changes, but it would help to know which relationships among neighbors and strangers became less violent and when. As Sharpe ${ }^{49}$ points out, the records of many counties survive from the years after the Civil Wars, but they have yet to be exploited, even to answer so basic a question as when personal violence subsided among members of the gentry. The importance of economic and demographic forces in diminishing neonaticide is clear, but as long as the data for other kinds of homicides are aggregated, the timing and the cause of the declines of each kind of homicide will remain unclear.

The homicide crisis that gripped England in the late sixteenth and much of the seventeeth century did not make England the most homicidal nation in Europe. Indeed, it may have been the least homicidal. Inquests from the Netherlands ${ }^{50}$, pardon papers from France ${ }^{51}$, and criminal examinations from Sweden and Finland $^{52}$, reveal homicide rates far in excess of those in English counties for which both inquests and indictments are available (Figures 15 and 16) ${ }^{53}$. Scholars have proposed a number of explanations for England's lower homicide rate: the suppression of noble feuds, the strength of its legal institutions, and its relative freedom from war on its own territory. Nonetheless, England suffered the same spike in homicide rates in the late sixteenth and early seventeenth centuries that most Scandinavian and Continental nations did, the same recession in homicide rates in the middle half of the seventeenth century, and the same low rate by the early eighteenth century.

Spierenburg (1998) shows that homicide rates declined in Amsterdam after 1620 because propertied, churchgoing citizens renounced violence; working class violence was undiminished. Ylikangas (2001) and Karonen (2001) demonstrate that politics played a critical role in determining homicide rates in Sweden and Finland. Homicide rates surged in the late sixteenth century, when civil strife left the central government too weak to suppress local violence. Homicide rates fell after 1630

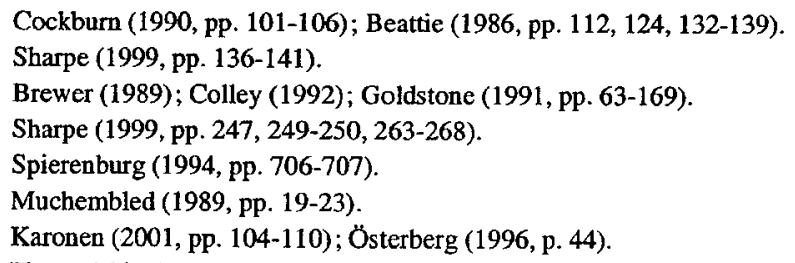

Figure 16 includes only urban homicide rates and excludes the rates for the smallest city, Vadstena, which followed a unique pattern, moving from the highest rate in 1540 (100 homicides per 100,000 persons per year) to a typical rate in the $1590 \mathrm{~s}$ and early $1600 \mathrm{~s}$ and then to the highest rate in the $1640 \mathrm{~s}$ and $1650 \mathrm{~s}$ (120 homicides per 100,000 persons per year) (Karonen, 2001, pp. 104-110). 


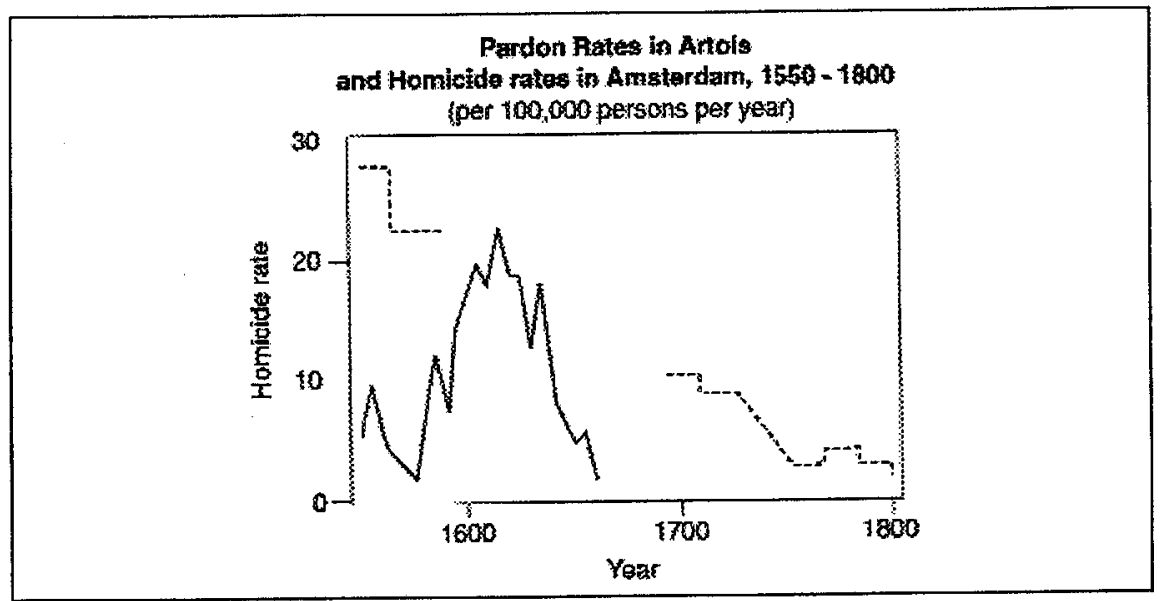

Figure 15.

Urban Homicide Rates in Sweden and Finland, $1550-1700$

(per 100,000 persons per year)

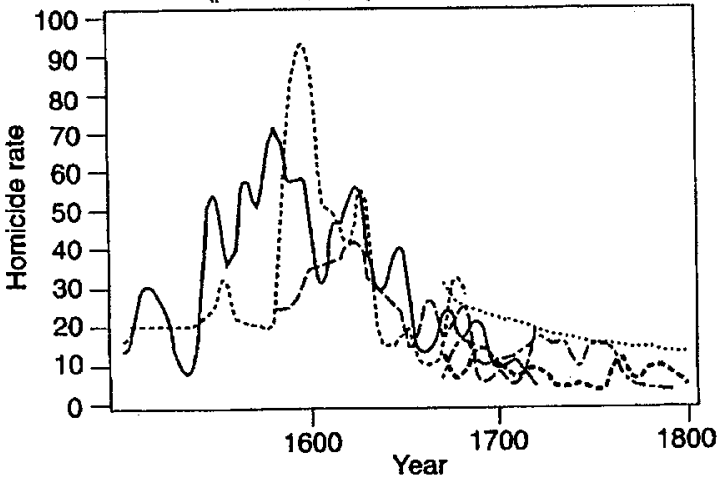

Figure 16.

because the strengthened government (with substantial support from local citizens and the clergy) replaced the traditional system of neighborhood justice, which compensated the families of homicide victims for their loss, with a modern system that held murders accountable to the state and meeted out stiffer penalties for murder, including death. Muchembled (1989) and Greenshanks (1994) argue similarly that the end of civil strife and the extension of the legal and police power of the central government diminished interpersonal violence in France after the Thirty Years' War and the Fronde. Such cultural, political, and institutional explanations may also explain homicide patterns in early modern England, but it will be impossible to know until the character and timing of England's homicides are as well understood as those of Scandinavia, the Low Countries, and France. 


\section{IMPROVING QUANTITATIVE UNDERSTANDING OF HOMICIDE}

Several things can be done to carry further the quantitative study of homicide that pioneering scholars of early modern England have begun. First, all available sources on homicide should be consulted. The returns to the King's Bench, for example, should be studied systematically so that scholars can move beyond the study of criminal indictments toward the study of homicide. County assize records have not survived for any jurisdiction prior to 1559 and for only the Home Counties and the Palatinate of Chester from 1559 through the English Civil Wars ${ }^{54}$. But the returns to the King's Bench have survived. A statute of 1487 authorized coroners to take fees for inquests performed in cases of murder or manslaughter and required that inquests that did not result in trials at the county assizes be returned to the King's Bench. The returns do not include homicide cases that were entered in the indictment files of the county assizes, nor do they contain inquests from boroughs that maintained independent courts. But they do contain inquests on a substantial number of homicides ${ }^{55}$. The returns to the King's Bench are not comprehensive for most counties before the 1530 s, and returns had ceased from most counties by the mid-seventeenth century. A statute of 1752 revitalized the system by paying coroners in nonborough jurisdictions a pound for each inquest that was returned, plus mileage and a surcharge of $13 \mathrm{~s}$. $4 \mathrm{~d}$. for inquests on homicide victims. The returns of many counties are comprehensive or nearly so after that date, and they include both homicides that resulted in criminal indictments and homicides that did not ${ }^{56}$.

The returns to the King's Bench contain a wealth of information, particularly on nondomestic homicides in which both the victim and the probable assailant were adults. County grand juries failed to indict mostly in cases of self-defense and in cases in which the victim or the alleged assailant (who had fled) were strangers to the community. The returns thus offer substantial evidence on random acts of violence, on the efficacy of law enforcement, and on the willingness of individuals to use lethal force to protect themselves, their families, or their property.

The impact of such cases on homicide rates in the sixteenth century was substantial. Estimating county populations in light of recent work by demographic historians (Appendix A), the returns to the King's Bench reported by Hunnisett (1985, 1969) for Sussex and Nottingham, 1530-1558, and by Cockburn (1990) for Kent, 1559-1599, raise homicide rates (excluding neonaticides, which appeared rarely in the returns) by one to four homicides per 100,000 persons per year, depending on the county and the decade (Table 3 ).

The surviving records of borough courts must also be examined if the contribution to homicide rates of towns and small cities is to be appreciated. The Cinque Ports of Sussex County, for instance, did not return their inquests systematically to the King's Bench in the mid-sixteenth century. A partial run of inquests that survives from Rye includes enough homicides to raise the homicide rate based on the returns of nonboroughs to the King's Bench, 1530-58, by fourteen percent (Hunnisett,

54 Cockburn (1985, pp. 1-41; 1975a, b; 1972).

55 MacDonald, (1990) makes the most impressive use of the King's Bench records to date, although it does so for suicides, not homicides. Its authors found over 20,000 inquests on suicides in the King's Bench records from 1485 to 1707 .

56

Hunnisett (1981, pp. xxix-xxxii). 
Table 3: Homicide Rates from Returns to the King's Bench.

\begin{tabular}{|l|c|c|c|}
\hline & Sussex & Nottingham & Kent \\
\hline $1530-9$ & 2.3 & 3.9 & - \\
\hline $1540-9$ & 2.8 & 2.6 & - \\
\hline $1550-8$ & 3.3 & 2.2 & - \\
\hline $1559-99$ & - & - & 1.0 \\
\hline
\end{tabular}

Sources: Hunnisett $(1969,1985)$ and Cockburn $(1990$, p. 74$)$. Cockburn states that «almost all» of the fifty-three additional homicide cases in Kent discovered in the returns to the King's Bench occurred in the sixteenth century, when the records were nearly complete (p. 74). The table assumes that five-sixths of the cases occurred before 1600 . If all had occurred before 1600 , the homicide rate from the returns would be 1.2 per 100,000 persons per year.

1985). Colchester was the only borough in Essex empowered to try felonies, but Sharpe ${ }^{57}$ finds evidence of 13 homicides in its fragmentary session rolls : enough to raise the homicide rate based on assize records, $1620-1680$, by seven percent. Given the historically large contribution of urban areas to homicide rates (a contribution based, according to Archer and Gartner ${ }^{58}$, «not on the absolute size» of the urban area but on «its size relative to its contemporary society»), it is crucial that borough records be studied.

A full study of the returns to the King's Bench and of surviving borough records would provide more accurate estimates of homicide rates in counties for which assize records have survived, as well as a national portrait of temporal trends and regional differences in nondomestic and urban homicide and in the ability of local communities and authorities to curb violence by and among strangers.

Of course, such methods would estimate only the rate at which homicides came within the purview of the courts. Inquests and indictments, however, are not the only sources available on early modern homicide. Newspapers, broadsides, pamphlets, diaries, and vital records proliferated by the eighteenth century and contain a wealth of information on murders. When and where such sources are available in addition to court records, it is possible to use statistical techniques to estimate the number of publicly-recognized homicides and suspected homicides that occurred, including those that left no trace in any surviving source. Scholars would need to make two lists: one of all homicides found in judicial sources (inquests, indictments, examinations) and one of all homicides found in nonjudicial sources (newspapers, pamphlets, etc.). The lists would then be matched to determine the number of homicides on both lists $(C)$, on the list from court records only $\left(\mathrm{N}_{\mathrm{c}}\right)$, and on the list from newspapers or other sources only $\left(\mathrm{N}_{\mathrm{n}}\right)$. Following the method of Chandra Sekar and Deming (1949), the proportion of homicides missed by both lists (X) can be estimated.

$$
\mathrm{X}=\left(\mathrm{N}_{\mathrm{c}} * \mathrm{~N}_{\mathrm{n}}\right) / \mathrm{C}
$$

57 Sharpe (1983, pp. 20, 123).

58 Archer, Gartner (1984, pp. 98-117). 
The result can be used to estimate the number of publicly recognized homicides (N) that occurred.

$$
\mathrm{N}=\mathrm{X}+\mathrm{N}_{\mathrm{c}}+\mathrm{N}_{\mathrm{n}}+\mathrm{C}
$$

The standard error of the estimate $\left(\mathrm{s}_{\mathrm{N}}\right)$ is equal to the square root of

$$
\left(\mathrm{N} * \mathrm{q}_{\mathrm{c}} * \mathrm{q}_{\mathrm{n}}\right) /\left(\mathrm{p}_{\mathrm{c}} * \mathrm{p}_{\mathrm{n}}\right)
$$

where

$$
\begin{aligned}
& p_{c}=C /\left(C+N_{n}\right) \\
& p_{n}=C /\left(C+N_{c}\right) \\
& p_{c}+q_{c}=p_{n}+q_{n}=1
\end{aligned}
$$

The Chandra Sekar and Deming method, which is based mathematically on the «capture-recapture» technique that biologists use to estimate wildlife populations, is robust. It does not require that the evidence from which the lists are drawn be comprehensive or complete, as long as the loss of records and the omissions of record keepers are random. It has been used successfully to estimate death rates for young children in Egypt (Becker et al. 1996), HIV-infection rates among drug addicts in Thailand (Mastro et al. 1994), and other vital and epidemiological rates in societies that lack effective means of registration or reporting (e.g. Crimmins 1980).

The capture-recapture method requires, however, that the matched lists be statistically independent, an assumption that does not hold for homicides as a whole. Certain homicides are more likely to appear on one list than on the other. The requirement for independence can be largely met by disaggregating the homicides on the lists into homogeneous groups based on geography, period, age of victim, etc., and by estimating the number of homicides separately for each group ${ }^{59}$. What interdependence between the lists of homicides remains after disaggregation will probably bias the estimates downward in the range of ten to fifteen percent (Eckberg 2001), but that bias should be consistent over time and is too small to account for the historic trends that appear in most homicide rates.

Of course, capture-recapture methods cannot estimate the number of homicides known only to the murderer, such as poisonings that neighbors and physicians misinterpreted as natural deaths. Only forensic anthropologists can uncover such murders. But capture-recapture methods can estimate the number of homicides and possible homicides that did not escape public notice.

It is possible, for example, to estimate homicide rates for European colonists in New England in the seventeenth and eighteenth centuries with considerable accuracy. As Table 4 shows, the surviving sources, depending on their quality in particular periods, capture an estimated $55 \%$ to $94 \%$ of all adult homicides. The estimates are lowest for the seventeenth century, especially the $1650 \mathrm{~s}$ and $1660 \mathrm{~s}$, for which most of Massachusetts's court records have been lost. The estimates are also low for the late 1770 s and early 1780 s, when the American Revolution disrupted local

59 Chandra Sekar, Deming (1949); Crimmins (1980); Hook, Regal (1995). 
courts and the dissemination of local news. Otherwise the surviving sources capture a high proportion of estimated homicides.

Table 4: Estimates from Matched Lists of the Number of European-American Adult Homicides in Connecticut, Massachusetts, Maine, and New Hampshire 1630-1797

\begin{tabular}{|l|c|c|c|c|c|c|c|}
\hline & $\begin{array}{c}1630- \\
1649\end{array}$ & $\begin{array}{c}1650- \\
1669\end{array}$ & $\begin{array}{c}1670- \\
1692\end{array}$ & $\begin{array}{c}1693- \\
1749\end{array}$ & $\begin{array}{c}1750- \\
1774\end{array}$ & $\begin{array}{c}1775- \\
1783\end{array}$ & $\begin{array}{c}1784- \\
1797\end{array}$ \\
\hline Located only in court records & 3 & 11 & 14 & 37 & 17 & 16 & 17 \\
\hline Located only in other sources & 28 & 4 & 6 & 8 & 11 & 18 & 5 \\
\hline $\begin{array}{l}\text { Located in court records } \\
\text { and in other sources }\end{array}$ & 6 & 3 & 8 & 22 & 44 & 21 & 32 \\
\hline Number of homicides found & 37 & 18 & 28 & 67 & 72 & 55 & 54 \\
\hline $\begin{array}{l}\text { Estimated number } \\
\text { of homicides }\end{array}$ & 51.0 & 32.7 & 38.5 & 80.5 & 76.2 & 68.7 & 56.7 \\
\hline $\begin{array}{l}\text { Percentage of estimated } \\
\text { homicides found }\end{array}$ & .73 & .55 & .73 & .83 & .94 & .80 & .95 \\
\hline $\begin{array}{l}\text { Standard error of estimated } \\
\text { homicides }\end{array}$ & 10.9 & 12.6 & 7.1 & 7.0 & 2.7 & 6.7 & 2.1 \\
\hline
\end{tabular}

Homicide rates estimated by capture-recapture methods present a more accurate picture of homicide trends. In colonial New England, the estimates show that European American homicide rates declined in three abrupt steps (Figure 17): at the end of the Pequot War (1636-1637), at the end of King Philip's War (1675-16766), and at the end of the Glorious Revolution (1688-1692). The era of frontier violence, during which the homicide rate stood at over 100 per 100,000 adults per year, ended in 1637 when English colonists and their Native American allies established their hegemony over New England. For the next thirty-eight years, the homicide rate for European colonists held steady at 7 to 9 per 100,000 adults per year - the same rate that probably prevailed in the heavily Puritan counties of southeastern England. The homicide rate fell again, however, in the next seventeen years to just over 1 per 100,000 adults per year - the lowest rate yet discovered in the early modern world. The sudden decline in homicide did not correlate with improved economic circumstances, stronger courts, or better policing. It did, however, correlate with the rise of intense feelings of Protestant and racial solidarity among the colonists, as two wars and a revolution united the formerly divided colonists against New England's native inhabitants, against the French, and against their own Catholic monarch, James II.

On the other hand, capture-recapture methods show that neonaticide and child murder rates changed gradually among New England's European inhabitants. The rates declined in the seventeenth century and rose again in the nineteenth century (Roth 2001). The rates correlate with the same variables that correlate with neonaticide indictment rates in early modern England. Neonaticide and child murder 


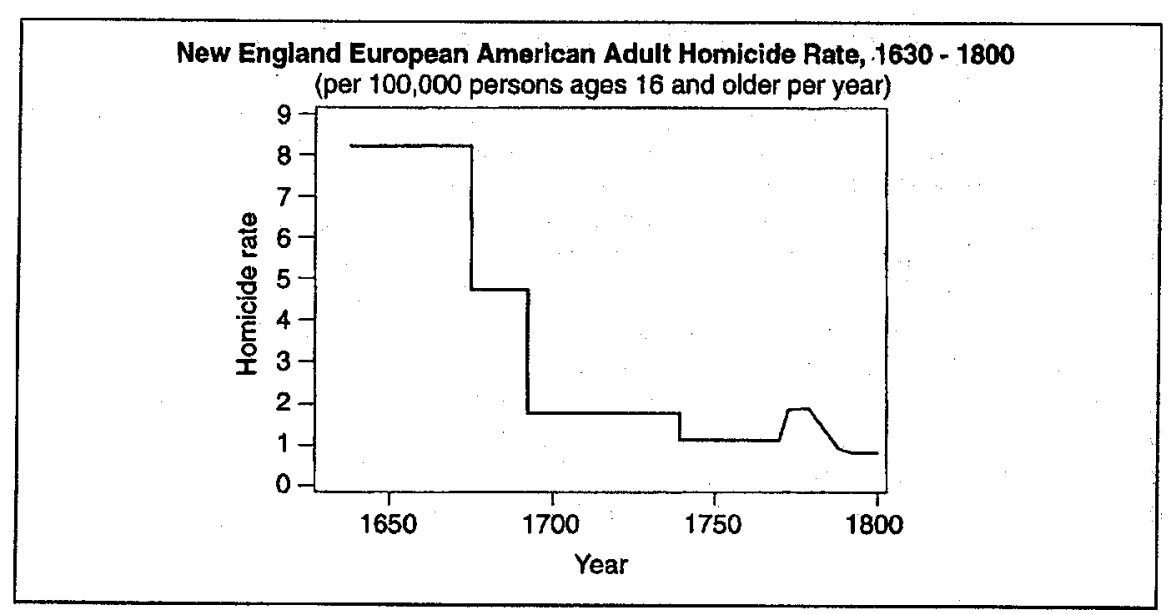

Figure 17.

declined as the birth rate rose, as the premaritial pregnancy rate soared, and as the age at which women first married fell. The patterns suggest that demographic conditions influenced neonaticide and child murder rates and that political events influenced adult homicide rates.

It may prove impossible to calculate precise, disaggregated homicide rates for England before the late seventeenth and early eighteenth centuries. Diaries and other non-court records may not be available. Even so, scholars could make better use of surviving court records. They could use statistical techniques to extrapolate homicide levels from counties with complete records of indictments and inquests to counties with incomplete records. For example, Eckberg (1995) uses an economic forecasting approach (based on generalized least squares regression) to estimate the homicide rate in the United States from 1900 through 1932. Eckberg uses the death registration statistics compiled by public health departments in states that met the federal standard for inclusion in the official Death Registration Area (DRA). The standard required that states record accurately the cause of death of at least $90 \%$ of the people who died in the state each year. In 1900, only the District of Columbia and a handful of New England and Mid-Atlantic states met the standards. As the years passed, more and more states met the standards, but the DRA was not national until 1933, when Georgia finally joined.

Eckberg uses an economic forecasting approach to retrodict annual homicide rates prior to 1933 for states that had yet to meet the DRA standards. Thus, for 1932, he estimates Georgia's homicide rate by regressing Georgia's homicide rates from 1933-1965 on the homicide rates for the other forty-seven states. He uses the resulting regression equation to estimate Georgia's homicide rate in 1932 from the homicide rates reported by the other states in 1932. The approach moves backward through time, year by year. The homicide rates of more and more states must be estimated from the homicide rates of fewer and fewer states, until the missing rates in 1900 are estimated from the homicide rates in the original DRA states. Eckberg's results are dramatic. They indicate with a high degree of statistical probability that the U.S. homicide rate did not increase from 1900 to 1933 , as had long been 
assumed. The homicide rate was stable: the number of high-homicide states in the DRA increased.

Econometric forecasting techniques could be used in several ways to improve understanding of homicide in early modern England. Indictment or inquest rates could be estimated for the years in which counties had gaps in their records and could be retrodicted for the years before a given county's records began. A case in point would be the counties of the Northern Circuit (Yorkshire, Cumberland, Westmorland, and Northumberland), whose surviving records begin in 1642 . Regression could be used to estimate the Northern Circuit's homicide indictment rate prior to 1642 from the indictment rates in Cheshire and the Home Circuit. Economic forecasting techniques could also use the returns to the King's Bench in the late sixteenth and early seventeenth centuries to retrodict indictment rates for counties whose assize records have been lost, if regression were to detect a close statistical relationship between inquest rates and indictment rates in the Home Counties and in Cheshire.

\title{
CONCLUSION
}

A quarter century ago, Elton ${ }^{60}$ remarked that it was «a pity» that the surviving statistics on early modern crime had not been « used more comprehensively». «The time has come to consolidate, and that consolidation calls for a more systematic and more critical analysis of the available sources than has yet been attempted. In this way, the deficiencies of the material will be properly pinpointed but they will also receive such remedy as can be got». Much progress has been made since Elton's remarks, but they are still timely.

\author{
Randolf Roth \\ Department of History \\ 106 Dulles Hall \\ 230 West 17 th Ave. \\ Columbus, $\mathrm{OH} 43210-1367$ \\ USA \\ roth.5@OSU.edu
}

60 Elton (1977, pp. 10, 13). 


\section{Appendix A}

\section{JUDICIAL EXAMINATIONS, INDICTMENTS, AND INQUESTS FOR NEONATICIDE AND HOMICIDE}

Counts of judicial examinations, indictments, and inquests are from the sources below. All counts except those for Kent, 1630-1800, and for Middlesex, 1549-1625, are corrected for missing data. The homicide counts for Middlesex are not directly comparable to the counts for other counties, because they include neonaticides. In the nineteenth century, Jeafferson (1886-92) published an edited edition of indictments and inquests from the session rolls and coroner's returns from Middlesex, which recorded many homicides. Jeafferson also tallied manslaughter and murder indictments, 1549-1624. It is uncertain how complete the Middlesex records or Jeafferson's edition of the records are, but the indictments Jeafferson reported follow the same pattern as indictments in other counties.

\section{Indictments only}

Cheshire, 1580-1709

Essex, 1620-1714

The Home Counties, 1559-1625

(Essex, Hertfordshire,

Kent, Surrey, and Sussex)

Surrey and Sussex, 1660-1800

\section{Indictments and inquests}

Kent, $1620-1800$

Middlesex, 1549-1624
Sharpe, 1999, p. 87.

Sharpe, 1983, p. 183, and Malcolmson, 1977, p. 337 n30.

Cockburn, 1975-82.

Beattie, 1986, pp. 90, 108, 115.

Cockburn, 1990, p. 94.

Jeafferson, 1886-92, v. 1 and v. 2, esp. pp. 245-314.

Hunnisett (1981).

\section{Judicial examinations only}

The Northern Circuit, 1720-1799 Jackson, 1996, p. 26 n61

(Cumberland, Northumberland, (neonaticides only).

Westmorland, Yorkshire) 


\section{Appendix B}

\section{ESTIMATES OF COUNTY-LEVEL POPULATION AND BIRTHS}

Following the method of Cockburn (1990, pp. 78-79), the county populations from 1700 to 1800 for the Home Counties, the Northern Circuit, Wiltshire, and Chester are interpolated from the estimates of Deane and Coale (1962, p. 103) and from The Population Returns of 1831 (1832, pp. 41-45). County populations prior to 1700 are determined by assuming that each county's population grew at the same rate as England's population as a whole as estimated by Wrigley, et al. (1997, p. 614). The number of births in each county in each decade are determined by multiplying the estimated county population the estimates of the crude national birth rate (CBR) in Wrigley, et al. $(1997$, p. 614). These estimates of total population and crude birth rates are similar to the earlier estimates of Wrigley and Schofield (1981, pp. 528-529). The differences between the earlier estimates, which were derived from parish registers (which included many registers from Cheshire and the Home Counties), and the later estimates, which were derived from family reconstitution, are small ${ }^{1}$. The estimates produce similar estimates of homicide and neonaticide indictment rates.

The population of Middlesex County, exclusive of London, is difficult to estimate. Its population doubtless grew faster than the national average, as did London's, but it is impossible to know precisely what portion of the county's population resided outside the borough of London and was thus under the jurisdiction of the Middlesex county court. The homicide rates reported in Table 2 assume that the population of Middlesex County outside London was 75,000 in 1600, and that its population grew from 1549 through 1625 at the same rate as London's, as estimated by Rappaport $\left(1989\right.$, p. 61) and by Wrigley $(1978, \text { p. } 215)^{2}$.

1 For a critique of the 1997 estimates in favor of the 1981 estimates, see Levine (1998, pp. 605-632). Levine focuses on mortality estimates and on the period after 1750. He acknowledges that the 1997 and 1981 estimates of population growth and birth rates are similar for the early modern period.

2 Rappaport (1989, p. 61) estimates that the population of London rose from 70,000 in 1550 to 150,000 in 1600 . Wrigley $(1978$, p. 215$)$ estimates that the population of London and its suburbs rose from 200,000 in 1600 to 400,000 in 1650 . Note that London south of the Thames did not lie in Middlesex County. 


\section{Appendix C}

\section{DEMOGRAPHIC AND ECONOMIC INDICATORS}

Figure 3: Birth Rate

The birth rate is represented by the gross reproduction rate in Wrigley, et al. $(1997$, p. 614). The rate has been smoothed. The gross reproduction rate follows the same curve as the net reproduction rate and the crude birth rate in Wrigley, et al. (1997, p. 614). It also follows the same curve as the birth ratio (the number of children ages 0 to 9 per woman ages 15 to 44 ), which can be calculated from Wrigley, et al. (1997, p. 615).

\section{Figure 4: Index of Real Wages}

The index of real wages, based on wholesale prices (index 1451-1475 =100), is from Goldstone (1986, pp. 5-33). The index has been smoothed. Goldstone integrates the indices of Lindert and Williamson (1983, p. 1-25) and Phelps Brown and Hopkins (1956, pp. 296-314, and 1957, pp. 289-306). Rappaport (1989, pp. 123$161)$ offers an index of real wages based on retail prices. According to Rappaport's index, real wages did not fall as far or as fast in the late sixteenth century as Goldstone's composite index indicates. Rappaport's index moved in the same direction as Goldstone's, however, and it extends only to 1609 , so Goldstone's index is used. Both indices may understate the degree of economic hardship in late sixteenth and early seventeenth century, which was exacerbated by unemployment, underemployment, and intermittent employment (Houston, 1995, pp. 71-72).

Figure 5 : Proportion of Women Who Never Married

The proportion of women who never married is from Goldstone (1986, p. 10). Goldstone integrates the series of Schofield (1985, pp. 2-20) and Weir (1984, pp. 341-355).

Figure 6: Average Age of Women at First Marriage

The average age of women at first marriage is from Wrigley, et al. (1997, p. 134).

Figure 7 : Illegitimate Births

The data on the proportion of births that were illegitimate is from Wrigley, et al. (1997, p. 224). The data integrates the series of Adair (1991) and Laslett (1980, pp. 1-65). The series has been smoothed.

Figure 8: Life Expectancy

Life expectancy at birth is from Wrigley, et al. (1997, p. 614). The series has been smoothed.

Figure 9: Foundling Rate

Foundling rate in London is from Fildes (1990, pp. 139-178). 


\section{REFERENCES}

Adair, R. L., Regional Variations in Illegitimacy and Courtship Patterns in England, 15381754, Ph.D. thesis, University of Cambridge, 1991.

Adair, R., Courtship, Illegitimacy and Marriage in Early Modern England, Manchester, Manchester University Press, 1996.

Amussen, S. D., An Ordered Society: Gender and Class in Early Modern England, London, Basil Blackwell, 1988.

Amussen, S. D., 'Being Stirred to Much Unquietness': Violence and Domestic Violence in Early Modern England, Journal of Women's History, 1994, 6, p.

Amussen, S. D., Punishment, Discipline, and Power: The Social Meanings of Violence in Early Modem England, Journal of British Studies, 1995, 34, p.

Archer, D. and R. Gartner, Violence and Crime in Cross-National Perspective, New Haven, Yale University Press, 1984.

Archer, I. W., The Pursuit of Stability: Social Relations in Elizabethan London, Cambridge, Cambridge University Press, 1991.

Beattie, J. A., Violence and Society in Early Modern England, in Doob, A. N, Greenspan E. L., (Eds.), Perspectives in Criminal Law: Essays in Honour of John L. J. Edwards, Aurora, Canada Law Book, 1984, pp. 36-60.

Beattie, J. A., Crime and the Courts in England, 1660-1800, Princeton, Princeton University Press, 1986.

Becker, S., Waheeb, Y., El-Deeb, B., et al., Estimating the Completeness of Under-5 Death Registration in Egypt, Demography, 1996, 33, pp. 329-339.

Beier, A. L., Vagrants and the Social Order in Elizabethan England, Past and Present, 1974, 64, pp. 1-29.

Beier, A. L., Masterless Men: The Vagrancy Problem in England, 1560-1640, London, Methuen, 1985.

Ben-Amos, I. K., Adolescence and Youth in Early Modern England, New Haven, Yale University Press, 1994.

Blaikie, A., Illegitimacy, Sex, and Society: Northeast Scotland, 1750-1900, Oxford, Clarendon Press, 1993.

Boswell, J., The Kindness of Strangers: The Abandonment of Children in Western Europe from Late Antiquity to the Renaissance, New York, Vintage, 1988.

Bowden, P. J., Agricultural Prices, Farm Profits and Rents, in Thirsk, J., (Ed.), The Agrarian History of England and Wales, Cambridge, Cambridge University Press, 1976, 4, pp. 593-695.

Brewer, J., The Sinews of Power: War, Money and the English State, 1688-1783, London, Unwin Hyman, 1989.

Cockburn, J. S., A History of English Assizes, 1558-1714, Cambridge, Cambridge University Press, 1972.

Cockburn, J. S., Assize Records as Historical Evidence, Journal of the Society of Archivists, 1975a, 5, pp. 215-231.

Cockburn, J. S., (Ed.), Calendar of Assize Records: Essex Indictments, Elizabeth I, London, Her Majesty's Stationery Office, $1975 \mathrm{~b}$.

Cockburn, J. S., (Ed.), Calendar of Assize Records, 10 v., London, Her Majesty's Stationery Office, 1975-1982.

Cockburn, J. S., The Nature and Incidence of Crime in England, 1559-1625: A Preliminary Survey, in Cockburn, J. S., (Ed.), Crime in England, 1550-1800, Princeton, Princeton University Press, 1977, pp. 49-71. 
Cockburn, J. S., (Ed.), Calendar of Assize Records : Essex Indictments, James 1 , London, Her Majesty's Stationery Office, 1982.

Cockburn, J. S., (Ed.), Calendar of Assize Records: Home Circuit Indictments, Elizabeth I and James I: Introduction, London, Her Majesty's Stationery Office, 1985.

Cockburn, J. S., Patterns of Violence in English Society : Homicide in Kent, 1560-1985, Past and Present, 1990, 130, pp. 70-106.

Cockburn, J. S., (Ed.), Calendar of Assize Records: Kent Indictments, Charles 11, 1676-1688, London, Public Record Office, 1997.

Cunningham, F. G., et al., Williams' Obstetrics, 20th ed., Stamford, Appleton and Lange, 1997.

Colley, L., Britons: Forging the Nation, 1707-1837, New Haven, Yale University Press, 1992.

Deane, P., Cole, W.A., British Economic Growth, 1688-1959, Cambridge, Cambridge University Press, 1962.

Delasselle, C., Abandoned Children in Eighteenth-Century Paris, in Forster, E. Ranum, P.M., (Eds.), Deviants and the Abandoned in French Society, Baltimore, Johns Hopkins University Press, 1978, pp. 47-82.

Dolan, F. E., Dangerous Familiars: Representations of Domestic Crime in England, 1550 1700, Ithaca, Cornell Univ. Press, 1994.

Eckberg, D. L., Estimates of Early Twentieth-Century U.S. Homicide Rates : an Econometric Forecasting Approach, Demography, 1995, 32, pp. 1-16.

Eckberg, D. L., Stalking the Elusive Homicide: A Capture-Recapture Approach to the Estimation of Post-Reconstruction South Carolina Killings, Social Science History, 2001, 25 , forthcoming.

Elton, G. R., Crime and the Historian, in Cockburn, J. S., (Ed.), Crime in England, 15501800, Princeton, Princeton University Press, 1977, pp. 1-14.

Emmison, F. G., Elizabethan Life: Home, Work and Land from Essex Willans and Sessions and Manorial Records, Chelmsford, Essex Court Council, 1976.

Everitt, A., The Community of Kent and the Great Rebellion, 1640-1660, Leicester, Leicester University Press, 1966.

Faber, S., Kindermoord, in het bijzonder in de 18e eeuw te Amsterdam, Bijdragen en Mededelingen betreffende de Geshiedenis der Nederlanden, 1978, 93, pp. 224-240.

Fildes, V., Maternal Feelings Re-assessed: Child Abandonment and Neglect in London and Westminster, 1550-1800, in Fildes V., (Ed.), Women as Mothers in Pre-Industrial England: Essays in Memory of Dorothy McLaren, London, Routledge, 1990, pp. 139178.

Foyster, E. A., Male Honour, Social Control, and Wife Beating in Late Stuart England, Transactions of the Royal Historical Society, 6th ser., 1996, 6, pp. 215-224.

Foyster, E. A., Manhood in Early Modern England: Honour, Sex and Marriage, London, Longman, 1999.

Garnham, N., The Courts, Crime and Criminal Law in Ireland, 1692-1760, Dublin, Irish Academic Press, 1996.

Goldstone, J. A., The Demographic Revolution in England: A Re-examination, Population Studies, 1986, 49, pp. 5-33.

Goldstone, J. A., Revolution and Rebellion in the Early Modern World, Berkeley, University of California Press, 1991.

Gowing, L., Domestic Dangers: Women, Words, and Sex in Early Modern London, Oxford, Oxford University Press, 1996.

Gowing, L., Secret Births and Infanticide in Seventeenth-Century England, Past and Present, 1997,156, pp. 108-114. 
Greenshanks, M., An Economy of Violence in Early Modern France, University Park, Pennsylvania State University Press, 1994.

Gurr, T. R., Historical Trends in Violent Crime: A Critical Review of the Evidence, Crime and Justice: An Annual Review of Research, 1981, 3, pp. 295-353.

Hanley, S. B., Yamamura, K., Economic and Demographic Change in Pre-Industrial Japan, 1600-1868, Princeton, Princeton University Press, 1977.

Henry, B., Dublin Hanged: Crime, Law Enforcement and Punishment in Late EighteenthCentury Dublin, Dublin, Irish Academic Press, 1974.

Herrup, C. B., The Common Peace: Participation and the Criminal Law in SeventeenthCentury England, Cambridge, 1987.

Hey, D. G., An English Rural Community: Myddle under the Tudors and Stuarts, Leicester, Leicester University Press, 1974.

Hindle, S., The Keeping of the Public Peace, in Griffiths, P., Fox, A., Hindle, S., (Eds.), The Experience of Authority in Early Modern England, New York, St. Martin's Press, 1996, pp. 213-248.

Hoffer, P. C., Hull, N. E. H., Murdering Mothers: Infanticide in England and New England, 1558-1803, New York, New York University Press, 1981.

Holmes, C., The Eastern Association in the English Civil War, Cambridge, Cambridge University Press, 1974.

Hook, E. B., Regal, R.R., Capture-Recapture Methods in Epidemiology: Methods and Limitations, Epidemiologic Reviews, 1995, 17, pp. 243-264.

House of Commons, The Population Returns of 1831 [Great Britain] (London: printed for the House of Commons by E. Moxon, 1832.

Houston, R. A., The Population History of Britain and Ireland, 1550-1750, New York, Cambridge University Press, 1995.

Hrdy, S. B., Mother Nature: Maternal Instincts and How They Shape the Human Species, New York, Ballentine Books, 1999.

Hufton, O. H., The Poor of Eighteenth-Century France, 1750-1789, Oxford, Clarendon Press, 1974.

Hunnisett, R. F., ed., Calendar of Nottinghamshire Coroners' Inquests, 1485-1558, Thoroton Society Record Series, 25, Nottingham, Thoroton Society, 1969.

Hunnisett, R. F., ed., Wiltshire Coroners' Bills, 1752-1796, Devizes, Wiltshire Record Society, 1981.

Hunnisett, R. F., (Ed.), Sussex Coroners' Inquests, 1485-1558, Sussex Record Society, 1985, 74. Hunt, M., Wife Beating, Domesticity and Women's Independence in Eighteenth-Century London, Gender History, 1992, 4, pp. 10-33.

Ingram, M., The Reform of Popular Culture? Sex and Marriage in Early Modern England, in Reay, B., (Ed.), Popular Culture in Seventeenth-Century England, London, Croom Helm, 1985, pp. 129-165.

Ingram, M., Church Courts, Sex and Marriage in England, 1570-1640, Cambridge, Cambridge University Press, 1987.

Ingram, M., Reformation of Manners in Early Modern England, in Griffiths, P., Fox, A., Hindle, S., (Eds.), The Experience of Authority in Early Modern England, New York, St. Martin's Press, 1996, pp. 47-88.

Jackson, M., New-Born Child Murder: Women, Illegitimacy and the Courts in EighteenthCentury England, Manchester, Manchester University Press, 1996.

Jansen, P., Poverty in Amsterdam at the Close of the Eighteenth Century, Acta Historiae Neerlandicae, 1978,10, pp. 98-114. 
Jeafferson, J. C., (Ed.), Middlesex County Records, London, Middlesex County Record Society, 1886-1892, $4 \mathrm{v}$.

Johansson, S. R., Deferred Infanticide: Excess Female Mortality during Childhood, in Hausfater, G., Hrdy, S.H., (Eds.), Infanticide: Comparative and Evolutionary Perspectives, New York, Aldine, 1984.

Karonen, P., A Life for a Life versus Christian Reconciliation: Violence and the Process of Civilization in the Kingdom of Sweden, 1540-1700, in Ylikangas, H., Karonen, P., Lehti, M., (Eds.), Five Centuries of Violence in Finland and the Baltic Area, Columbus, Ohio State University Press, 2001, pp. 1-83.

Kelly, J., Harvests and Hardship: Famine and Scarcity in the Late 1720s, Studia Hibernica, 1991-1992, 26, pp. 65-103.

Kelly, J, Infanticide in Eighteenth-Century Ireland, Irish Economic and Social History, 1992, 19 , pp. 5-26.

Kelly, J., Scarcity and Poor Relief: The Subsistence Crisis of 1782-84, Irish Historical Studies 1992-1993, 28, pp. 38-62.

Kennedy, L., Dowling, M.W., Prices and Wages in Ireland, 1700-1850, Irish Economic and Social History 1997, 34, pp. 62-104.

Kertzer, D., Sacrificed for Honor: Child Abandonment in Italy, Boston, Beacon Books, 1993.

Knight, B., Forensic Pathology, 2nd ed., London, Arnold, 1996.

LaFleur, W., Liquid Life: Abortion and Buddhism in Japan, Princeton, Princeton University Press, 1992.

Laslett, P., Introduction: Comparing Illegitimacy over Time and between Cultures, in Laslett, P., Oosterveen, K., Smith, R.M., (Eds.), Bastardy and Its Comparative History, London, 1980, pp. 1-65.

Lawson, P., Property Crime and Hard Times in England, 1559-1624, Law and History Review, 1986, 4, pp 95-127.

Lee, J. Z., Campbell, C., Tan, G., Infanticide and Family Planning in Late Imperial China: The Price and Population History of Rural Liaoning, 1774-1873, in Rawski, T. G., Li, L. M., (Eds.), Chinese History in Economic Perspective, Berkeley, University of California Press, 1992, pp. 145-176.

Lee, J. Z., Fen, W., One Quarter of Humanity: Malthusian Mythology and Chinese Realities, 1700-2000, Cambridge, Harvard University Press, 1999.

Levine, D., Reproducing Families: The Political Economy of English Population History, Cambridge, Cambridge University Press, 1987.

Levine, D., Sampling History: The English Population, Journal of Interdisciplinary History, 1998,28 , pp. 605-632.

Lindert, P. Williamson, J., English Living Standards during the Industrial Revolution, Economic History Review, 2nd. ser., 1983, 36, pp. 1-25.

MacDonald, M., Murphy, T.R., Sleepless Souls: Suicide in Early Modern England, Oxford, Clarendon Press, 1990.

McIntosh, M. K., A Community Transformed: The Manor and Liberty of Havering, 1500 1620, Cambridge, Cambridge University Press, 1991.

McLaren, A., Reproductive Rituals: The Perception of Fertility in England from the Sixteenth to the Nineteenth Century, London, Methuen, 1984.

McNeil, D. R., Interactive Data Analysis, New York, Wiley, 1977.

Malcolmson, R. W., Infanticide in the Eighteenth Century, in Cockburn, J. S., (Ed.), Crime in England, 1550-1800, Princeton, Princeton University Press, 1977, pp. 187-209.

Martz, L., Poverty and Welfare in Hapsburg Spain: The Example of Toledo, Cambridge, Cambridge University Press, 1983. 
Mastro, T. D., Kitayaporn, D., Wegner, B.G. et al., Estimating the Number of HIV-Infected Drug Users in Bangkok: A Capture-Recapture Method, American Journal of Public Health, 1994, 84, pp. 1094-1099.

Michalik, K., Kindsmord: Sozial- und Rechtsgeschichte der Kindstötung im 18. und beginnenden 19. Jahrhundert am Beispiel Preußen, Pfaffenweiler, Centaurus-Verlagsgesellschaft, 1997.

Morrill, J. S., Cheshire, 1630-1660: County Government and Society during the English Revolution, Oxford, Oxford University Press, 1974.

Morrill, J. S., Revolt in the Provinces: The People of England and the Tragedies of War, 1630 I648, 2nd ed., New York, Longman, 1999.

Muchembled, R, La violence au village: sociabilité et comporetments populaires en Artois du XV au XVII siècle, Turnhout, Editions Brepols, 1989.

Mull, D. S., Mull, J.D., Infanticide Among the Tarahumara of the Mexican Sierra Madre, in Scheper-Hughes, N., (Ed.), Child Survival: Anthropological Perspectives on the Treatment and Maltreatment of Children, Dordrecht, D. Reidel, 1987.

Österberg, E., Criminality, Social Control, and the Early Modern State: Evidence and Interpretations in Scandinavian Historiography, in Johnson, E. A., Monkkonen, E.H., (Eds.), The Civilization of Crime: Violence in Town and Country since the Middle Ages, Urbana, University of Illinois Press, 1996, pp. 35-62.

Phelps Brown, E. H., Hopkins, S.V., Seven Centuries of the Prices of Consumables, compared with Builders' Wage-rates, in Carus-Wilson, E. H., (Ed.), Economica, 1956, 23, pp. 296-314.

Phelps Brown, E. H., Hopkins, S.V., Wages and Prices: Evidence for Population Pressure in the Sixteenth Century, Economica, 1957, 24, pp. 289-306.

The Population Returns of 1831 [Great Britain], London, printed for the House of Commons by E. Moxon, 1832.

Rappaport, S., Worlds within Worlds: Structures of Life in Sixteenth-Century London, New York, Cambridge University Press, 1989.

Roth, R., Did Class Matter in American Politics? The Importance of Exploratory Data Analysis, Historical Methods, 1998, 31, pp. 5-25.

Roth, R., Child Murder in New England, Social Science History, 2001, 25, forthcoming.

Rowlands, M. B., Masters and Men in the West Midland: Metalware Trades before the Industrial Revolution, Manchester, Manchester University Press, 1972.

Schleper-Hughes, N., Saints, Scholars, and Schizophrenics: Mental Illness in Rural Ireland, Berkeley, University of California Press, 1982.

Schofield, R. S., English Marriage Patterns Revisited, Journal of Family History, 1985, 10 , pp. 2-20.

Sharpe, J. A., Domestic Violence in Early Modern England, The Historical Journal, 1981, 24, pp. 29-48.

Sharpe, J. A., Crime in Seventeenth-Century England: A County Study, Cambridge, Cambridge University Press, 1983.

Sharpe, J. A., The History of Crime in England c. 1300-1914, British Journal of Criminology, 1988,28, pp. 254-267.

Sharpe, J. A., Crime in England: Long-Term Trends and the Problem of Modernization, in Johnson, E. A., Monkkonen, E.H., (Eds.), The Civilization of Crime: Violence in Town and Country since the Middle Ages, Urbana, University of Illinois Press, 1996, pp. 17-34.

Sharpe, J. A., Crime in Early Modern England, 1550-1750, 2nd. ed., New York, Addison Wesley Longman, 1999. 
Skipp, V., Crisis and Development: An Ecological Case Study of the Forest of Arden, 15701674, Cambridge, Cambridge University Press, 1978.

Slack, P. A., Vagrants and Vagrancy in England 1598-1664, Economic History Review, 2nd ser., 1974, 27, pp. 360-379.

Slack, P. A., Poverty and Policy in Tudor and Stuart England, London, Longman, 1988.

Slack, P. A., The English Poor Law, 1531-1782, New York, Cambridge University Press, 1995.

Smith, T. C., Nakahara: Family Farming and Population in a Japanese Village, 1717-1830, Stanford, Stanford University Press, 1977.

Spierenburg, P., Faces of Violence: Homicide Trends and Cultural Meanings: Amsterdam, 1431-1816, Journal of Social History, 1994, 27, pp. 701-716.

Spierenburg, P., Long-Term Trends in Homicide: Theoretical Reflections and Dutch Evidence, Fifteenth to Twentieth Centuries, in Johnson, E. A., Monkkonen, E.H., (Eds.), The Civilization of Crime: Violence in Town and Country since the Middle Ages, Urbana, University of Illinois Press, 1996, pp. 63-105.

Spierenburg, P., Knife Fighting and Popular Codes of Honor in Early Modern Amsterdam, in Spierenburg, P., (Ed.), Men and Violence: Gender, Honor, and Rituals in Modern Europe and America, Columbus, Ohio State University Press, 1998, pp. 103-127.

Spufford, M., Contrasting Communities: English Villages in the Sixteenth and Seventeenth Centuries, Cambridge, Cambridge University Press, 1974.

Steckel, R., A Dreadful Childhood: The Excess Mortality of American Slaves, Social Science History, 1986, 10, pp. 427-465.

Stone, L., Interpersonal Violence in English Society, 1300-1800, Past and Present, 1983, 101, pp. 22-23.

Tupling, G. H., The Economic History of Rossendale, new series, 86, Manchester, Chetham Society, 1927.

Ulrich, L. T., A Midwife's Tale: The Life of Martha Ballard, Based on Her Diary, 1785-1812, New York, Alfred A. Knopf, 1990.

Underdown, D., Revel, Riots, and Rebellion : Popular Politics and Culture in England, 1603 1660, Oxford, Clarendon Press, 1985.

Underdown, D., Fire from Heaven : Life in an English Town in the Seventeenth Century, New York, Harper Collins, 1992.

Van Eeghen, I. H., Vondelingen, Maandblad Amstelodamum 1956, 43, p. 130.

Van Nierop, L., De keuren tegen 'het ombrengen van jonge-gebore kinderen' in der $17 \mathrm{de}$ en 18de eeuw, Maandblad Amstelodamum, 1959, 40, 6, pp. 154-155.

Velleman, P. F., Hoaglin, D.C., Applications, Basics, and Computing of Exploratory Data Analysis, Boston, Duxbury Press, 1981.

Walter, J., The Social Economy of Dearth in Early Modern England, in Walter, J., Schofield, R.S., (Eds.), Famine, Disease and the Social Order in Early Modern Society, Cambridge, Cambridge University Press, 1989, pp. 75-128.

Walter, J. Schofield, R., Famine, Disease and Crisis Mortality in Early Modern Society, in Walter, J., Schofield, R.S., (Eds.), Famine, Disease and the Social Order in Early Modern Society, Cambridge, Cambridge University Press, 1989, pp. 1-74.

Walter, J., Wrightson, K., Dearth and the Social Order in Early Modern England, Past and Present, 1976, 71, pp. 22-42.

Weir, D., Rather Never than Late: Celibacy and Age at Marriage in English Cohort Fertility, 1541-1871, Journal of Family History, 1984, 9, pp. 341-355.

Wiener, C. Z., Sex Roles and Crime in Late Elizabethan Hertfordshire, Journal of Social History, Summer, 1975, 8, pp. 38-60. 
Wrightson, K., Infanticide in Earlier Seventeenth-Century England, Local Population Studies, 1975, 15, pp. 10-22.

Wrightson, K., Two Concepts of Order: Justices, Constables and Jurymen in seventeenthcentury England, in Brewer, J. Styles, J., (Eds.), An Ungovernable People: The English and Their Law in the Seventeenth and Eighteenth Centuries, London, Hutchinson, 1980, pp. 21-46.

Wrightson, K., English Society, 1580-1680, London, Hutchinson, 1982.

Wrightson, K., The Politics of the Parish in Early Modern England, in Griffiths, P., Fox, A., Hindle, S., (Eds.), The Experience of Authority in Early Modern England, New York, St. Martin's Press, 1996, pp. 10-46.

Wrightson, K., Levine, D., Poverty and Piety in an English Village: Terling, 1525-1700, New York, Academic Press, 1974.

Wrightson, K., Levine, D., The Making of an Industrial Society: Whickham, 1560-1765, Oxford, Clarendon Press, 1991.

Wrigley, E. A., A Simple Model of London's Importance in Changing English Society and Economy, 1650-1750, in Abrams, P., Wrigley, E.A., (Eds.), Towns in Societies: Essays in Economic History and Historical Sociology, New York, Cambridge University Press, 1978, pp. 215-243.

Wrigley, E. A., Davies, R.S., Oeppen, J.E., Schofield, R.S., English Population History from Family Reconstitution, 1580-1837, New York, Cambridge University Press, 1997.

Wrigley, E. A., Schofield, R.S., The Population History of England, 1541-1871: A Reconstruction, New York, Cambridge University Press, 1981.

Ylikangas, H., What Happened to Violence? An Analysis of the Development of Violence from Medieval Times to the Early Modern Era Based on Finnnish Source Material, in Ylikangas, H., Karonen, P., Lehti, M., (Eds, Columbus, Ohio State University Press, 20), Five Centuries of Violence in Finland and the Baltic Area 01, pp. 1-83.

Zell, M., Industry in the Countryside: Wealden Society in the Sixteenth Century, New York, Cambridge University Press, 1994. 